\section{Towards Transparency as a Global Norm}

\author{
ANNE PETERS*
}

\section{The 'Transparency Turn'1 in Global Governance}

Transparency has been called 'an overused but underanalysed concept'. ${ }^{2}$ This certainly holds true for contemporary international law. In all major fields of international law - e.g. environmental law, economic law, human rights law, international humanitarian law, health law, peace-and-security law - demands for more transparent institutions and procedures have recently been voiced by civil-society actors, by States, and within the international institutions themselves. This book tries to identify and map these quests and responses and to fill the analytical gap surrounding them. Its overall aspiration is to obtain a cross-section of the developments and debates in various areas of international law in order to lay the foundations for a broader and more systematic analysis of 'global transparency'.

Transparency is here understood as a culture, condition, scheme or structure in which relevant information (for example on law and politics) is available. ${ }^{3}$ Generally speaking, if something is transparent, you can see through it. The opposites of transparency are not only opaqueness (opacity), secrecy and confidentiality, but also complexity and

* I thank my collaborators and authors Orna Ben-Naftali, Andrea Bianchi, Megan Donaldson, Lukas Musumeci, Thore Neumann and Roy Peled for careful reading and for lucid remarks on a previous version of this chapter. I am also indebted to my co-Fellows at the Wissenschaftskolleg for useful feedback: Kelly Askew, Hubertus Buchstein, Delphine Gardey, Bruce Kogan, Cristina Lafont, and Ussama Makdisi. Their input has hopefully helped improve the chapter; all remaining deficits are attributable to me

I borrow this term from Aarti Gupta, 'Transparency under Scrutiny: Information Disclosure in Global Environmental Governance', Global Environmental Politics 8 (2008), 1-7, 6 (which the author used in discussing environmental governance).

2 Ibid., 1.

${ }^{3}$ See for the concept in detail Andrea Bianchi, 'Introduction: On Power and Illusion. The Concept of Transparency in International Law', chapter 1 in this volume. disorder. The multitude of antonyms shows that the concept of transparency has multiple meanings itself, inter alia depending on the context. Concepts related to 'transparency' are 'publicity', 'publicness' and 'openness'. While notably 'publicity' is a traditional term of political 'opery and philosophy, transparency has become a more recent buzzword Strictly speaking transparency is the mere accessibility of information, whereas publicity is the fact that information is actually accessed ${ }^{4}$ Although transparency is no guarantee that publicity will really come about, these two terms will be used interchangeably in this chapter.

The preceding chapters of this book have analysed the obligees and The priaries of transparency obligations in international law: who owes

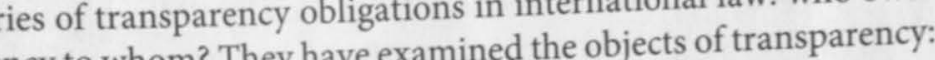
transparency to whom? They have examined the objectures, meetings, what has been made transparent - institutions, procedures, documents? They have analysed the objective of transparency: to what end? They have looked at the timing: is transparency brought about in real time or in retrospect? They have looked at sanctionability: can non-disclosure be challenged and does unjustified non-disclosure involve any sanctions (of a legal or political kind or impinging on someone or something's reputation)? And finally the book has examined the scope and nature of exceptions to transparency. Cross-cutting chapthe ters have add enteren 19 by Megan Donaldson application, and dispute settlement ${ }^{6}$. Chapter 19 by and Benedict Kingsbury shows that many internicies which have comhave adopted internal rules on transparency policies which have?

mon features, resembling national freedom of information laws.

The objective of this concluding chapter is fourfold. First, it seeks to draw together the findings from the chapters, against the background of the aims of the entire project and the research questions embed these above (especially in sections 5-7). Second, it seeks to embed these

4 Daniel Naurin, 'Transparency, Publicity, Accountability - The Missing Links', Swiss Political Science Review 12 (2006), 90-98, 91

(Thaw-Making', chapter

tency in International Law-Making', chapter 16 in this volume.

6 Then in International Adjudication', chapter 17 in this volume.

Grigorescu, 'Transparency of Intergovernmental Organizations: The Roles of Member States, International Bureaucracies and Nongovernmental Organizations, Intermational Studies Quare likely to be more transparent, and why. 
findings within the broader transparency debate. This includes a discussion of the specific significance of transparency as a practice and principle in the context of globalization (sections 3-4), relations between transparency and normative concepts such as legitimacy, democracy and accountability (sections 8-13), reflections on the value, functions, and drawbacks of transparency in international law and governance, specifically in comparison to (and in combination with) domestic transparency (sections 10 and 14), and an account of the legal status of a possible transparency norm, including its relation to the human right of information (sections 4 and 17). Third, the chapter makes policy proposals for regulating transparency, especially with regard to exceptions needed for deliberations (section 15.2). Finally, this chapter interprets the rise of transparency in international law as a manifestation of a paradigm shift from a 'private' to a 'public' law-character of international law and in the end identifies lines for further research (section 19).

To begin, the overall findings of this book's chapters are striking. Institutions, processes and mechanisms in international law have, on balance, become more transparent. In addition, the trend is away from merely 'reactive' towards more 'proactive' transparency. ${ }^{8}$ States and international organizations no longer espouse only a passive posture namely in allowing the information to be available to others if the latter so choose or if they request access or have the time, means and skills to look. Rather, the relevant entities engage in active disclosure policies. These can range from public relations measures and image campaigns (notably in the business sector) ${ }^{9}$ to outright disinformation and propaganda. All that has happened basically since the turn of the millennium.

${ }^{8}$ Helen Darbishire, 'Proactive Transparency: The Future of the Right to Information?', World Bank Institute Governance Working Paper Series No. 56598 (2010). For the EU in different terms ('active' and 'passive' transparency), see Anne Peters, Elemente einer Theorie der Verfassung Europas (Berlin: Duncker \& Humblot, 2001), 694-697; CarlSebastian Zoellner, 'Transparency: An Analysis of an Evolving Fundamental Principle in International Economic Law', Michigan Journal of International Law 27 (2006), 579-628, 627; for international adjudication Thore Neumann/Bruno Simma, Transparency in International Adjudication', chapter 17 in this volume.

See also Thomas N. Hale, 'Transparency, Accountability and Global Governance', Global Governance 14 (2008), 73-94, 75, who defines transparency as ranging from answering inquiries to general disclosure (making unsolicited informationging from Richard W. Oliver, What is Transparency? (New York. McGraw-Hill, 2004), 3-4 calls the proactive posture the 'new transparency'.
Larry Catá Backer, 'Transparency and Business

between Norm and Technique', chapter 18 in this volume.

\section{Mirroring Domestic Transparency?}

This This novel international domestic law, namely the 'freedom of information development within domestic law, namely the 'freedom explosion $^{10}$ of the 1990s. In modern democratic States, ever since the eighteenth century, the publicity (or transparency) of the legislative process $^{11}$ and its acts and statutes as well as of judicial proceeding have been considered necessary elements of democracy and the rule of law. In contrast, and for a much longer period, the working of the executive branch, both at the level of high politics and in day-to-day administration, has been partly secret. Transparency in this regard has been created by worldwide freedom of information laws which grant

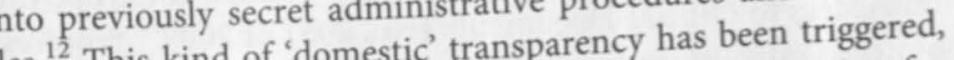
trative files. ${ }^{12}$ This kind of 'domestic' transparency has been trigg for inter alia, by environmental and consumer movements pressing for information on environmental impact and the risks associated with certain products, as well as by the rise of the concept of 'New Public Management' with its expectation that transparency will increase the effectiveness of administrative activity. Additionally, transnationally active NGOs (such as Art. 19, ${ }^{13}$ Transparency International, and the Open Society Foundations ${ }^{15}$ ), international organizations, and international treaty regimes have pressed for the transparency of States. The Organization for Economic Co-operation and Development (OECD), the World Bank, the Council of Europe, the WTO, and other internathential component encouraged, if not mandated, recipients of of good governance and encouraged, if not mandated, recipies to adopt aid, borrower States, and more generally their member States to adopt

to John M. Acker' Administrative Law Review 58 (2006), 85-130; Patrick Birkinshaw, Information Laws, Administrative Law Rractice and the Ideal (Cambridge University Freedom of Information: The

Press, 4th edn, 2010), 498. See Delphine Gardey, "Enregistrer" et rendre lesce et révélateur de la démocratie en France. La sténographie comme exigence et revelolivier Rozenberg (eds.), Faire parlementaire?', in Cécile Vigour/Claire De Galembert/Oriverentaires pour les sciences parler le parlement: Méthodes et enjeux des debats parlemce, forthcoming).

sociales (Paris: Librairie générale de droit et de jurisprudence, Toby Mendel, Freedom of

12 For comparative surveys of freedom of information laws, see T): David Banisar, 'Freedom Information: A Comparative Legal Survey (Paris: UNESCO, 2008), Daww.freedominfo.org/ Information:A around the World 2006, 2006, available at: www.freedominfo.org documents/global_survey2006.pdf.

13 www.

15 www.opensocietyfoundations.org. 
freedom of information laws, or at least become transparent in certain specific sectors such as trade legislation and policy. This strategy has been closely linked to the global fight against corruption, which has been recognized as a major obstacle to the realization of the core objectives of global governance - namely economic and societal development, protection of human rights, respect for the rule of law, and development. For example, the 2003 UN Convention against Corruption (UNCAC) asks each State party to 'develop and implement or maintain effective, coordinated anti-corruption policies that promote the participation of society and reflect the principles of the rule of law, proper management of public affairs and public property, integrity, transparency and accountability. ${ }^{, 16}$ For similar reasons, the Council of Europe Convention on Access to Official Documents (No. 205) of $2009^{17}$ requires member States to establish systems of access to their documents. A core question of this study is whether the demonstrated trend towards more international transparency is basically a repetition and reflection of that domestic development or whether it can be better understood as something different, either in part or in whole.

\section{Transparency and Globalization}

\subsection{The Globalized Information Society}

We are living in an 'information society, ${ }^{18}$ in the 'information age, ${ }^{19}$ an age in which information is a crucial resource of power and well-being. Richard W. Oliver speaks of an 'information-transparency cycle':

${ }^{16}$ UNGA, Report of the Ad Hoc Committee for the Negotiation of a Convention against Corruption on the Work of Its First to Seventh Sessions, A/58/422, 7 October 2003, annex: United Nations Convention against Corruption, art. 5 (emphasis added). See also arts. $7,9,10$ and 13 , requiring transparency in the public sector and in public procurement, which also demands public reporting, and transparency and participation in public decision-making.

17 Council of Europe Convention on Access to Official Documents, 18 June 2009, CETS No. 205 , not yet in force. The convention needs ten ratifications, and currently has six: Bosnia and Herzegovina, Hungary, Lithuania, Montenegro, Norway and Sweden. Eight States have signed but not yet ratified: Belgium, Estonia, Finland, Georgia, Moldova, Serbia, Slovenia and Macedonia.

${ }^{18}$ Scott Lash, Critique of Information (London: Sage Publications, 2002)

19 Manuel Castells, The Information Age: Economy, Society and Culture (Malden/Oxford: Wiley-Blackwell, 2nd edn, 2010). information is demanded, so more information is collected, and then more is yet again demanded. ${ }^{20}$

This information-transparency cycle has become globalized. It is globalized in the first sense that improved information and network technology is an important building-block of globalization. New techniques have rendered much cheaper and faster the provision and transfer of information, for example by allowing States to place huge numbers of files on governmental websites and offering citizens the technical means to search and retrieve documents. Internet-law specialist Lawrence Lessing has put this as follows: ' $[\mathrm{t}]$ he naked transparency movement merries the power of network technology to the radical decline in the cost of collecting, storing, and distributing data. ${ }^{21}$ While the availability of new technology as such does not in itself create more transparency and may even contribute to intransparency through 'data snowing' or and 22 rides 'data $\mathrm{smog}{ }^{22}$ on balance it has indeed furthered transparency. Besides governments, globally active business (Google as the paradigmatic firm) and unauthorized action (exemplified by WikiLeaks) ${ }^{23}$ contribute to the information-transparency cycle.

The information-transparency society is also globalized in a second sense, namely that in order to remain a resource of power and well-being, information (and transparency) must be available in a transboundary fashion for reasons which will now be explained.

\subsection{Globalization-induced Intransparency}

Globalization ${ }^{24}$ and global governance have, in at least three regards, created a novel degree of political intransparency that calls for compensatory transparency measures. First, both the increasingly global nature of political issues and the concomitant transfer of tasks and powers to international institutions have modified the nature and activity of nation-States. Even if these States, under their domestic-law obligations,

${ }^{20}$ Oliver, What is Transparency? 2004 (n 8), 22.

${ }^{21}$ Lawrence Lessing, 'Against Transparency', The New Republic (9 October 2009).

22 Coined by David Shenk, Data Smog (New York: Harper Collins, 1997),

${ }^{23}$ See Andrea Bianchi, 'Introduction: On Power and Illusion. The Concept of Transparency in Internation Law', chapter 1 in this volume, section 4.

24 Globalization is here understood as the increased transboundary flow of goods, persons, money and pollutants; the resulting economic, financial and environmental interdependency of States and other political actors; the extraterritorial effects of political decision-making at the national level; and the concomitant need for joint political and legal responses. 
must be transparent vis-à-vis their citizenry, State transparency is no longer sufficient to guarantee the overall transparency needed to hold the relevant power-holders to account because the States are no longer the only ones to wield political power. Second, State activity has many more extraterritorial effects that impact persons situated outside the acting State's boundaries. Substantially affected persons have a legitimate interest in being informed as to these extraterritorial activities but still face a higher degree of intransparency than that which usually exists within a State's borders. Third, the distribution of governmental functions among different actors, including those placed 'above' the States, in itself creates a new intransparency. Multilevel governance, the multiplication of centres of authority (polycentrism) and network-type structures make governance less transparent than ever before. Decision-making on the international level is not only often less transparent than within a State but the interplay between the multiple levels increases the intransparency. The net result is an overall reduction of transparency and notably of that kind of transparency needed to allocate responsibility for political action. $^{25}$

\subsection{Compensatory Transparency}

These three types of globalization-induced intransparency suggest that in order to at least preserve the current level of transparency there are two things necessary. First, the transparency obligations of States must be extended to new types of beneficiaries such as foreign States, international organizations, and to those natural or legal persons not formally under a State's jurisdiction but substantially affected by its policy decisions. Second, new types of transparency obligees must be envisaged in order to compensate for that loss of transparency which is incurred by global governance and the extraterritorial effects of State activity. A functional argument in favour of extending transparency obligations to international actors compares globalization to privatization. Privatization comprises the phenomenon of outsourcing - entities which are private-law constructs in form have been entrusted with the fulfilment of public tasks (furnishing of infrastructure, running prisons, etc.) and endowed with specific powers and funds to that end. It is generally thought that these should be subject to similar legal standards

${ }^{25}$ See Jürgen Bröhmer, Transparenz als Verfassungsprinzip (Tübingen: Mohr Siebeck, 2004), 376. as formally public entities are, in order to secure proper fulfilment of these tasks and prevent the abuse of powers. ${ }^{26}$ This functional consideration has motivated ever more domestic law-makers to extend the scope of application of statutes relating to information (both data protection and access to document laws) to formally private actors who Following this logic the Council of Europe exercise public functions. Following this logic, the Council of Europe Convention on Access to Official Documents of 2009 held by 'public authorities', additionally states that each party may 'declare that the definition of "public authorities" also includes (...) natural or legal persons insofar as they perform public functions or operate with public funds, according to national law. ${ }^{27}$

This line of reasoning can be extended to international organizations. Formally, these are constituted by States and are inter-public entities. From a functional perspective, they are performing tasks in the interest of all States and/or of the global publics. The policy suggestion then is that the same requirements of transparency should be imposed when public functions are 'zoned up' to actors 'above' the nation-State. The reason for this dual extension is that oversight and control is desirable in these cases as well. The exercise of functionally public power should be accompanied by accou mation is a vehicle to bring this about.

It is therefore reasonable that international organizations should be subject to similar transparency requirements as States. The wording of Convention No. $205^{28}$ would seem to allow member States to designate international organizations - which perform public functions and operate with public funds - as 'public authorities' in this sense and subject them to the Convention's transparency requirements, then operative as domestic law.

To conclude, the more intense global governance becomes, the more it takes over functions that were previously fulfilled by domestic actors. Because of this impact and because of these functions, global governance

26 A different matter is that all business actors (beyond those who are entrusted with public function functions) exercise some type of 'economic powe' which on thecause it differs from not in itself justify imposing transparency requirements on them because it in a common political power, a special type of power created by drawing together peoplein a comm Press, undertaking (Martin Loughlin, Foundations of Public Law (Ox 2010), 11)

27 Convention No. 205, 2009 (n 17), art. 1(2)(a)(ii)(3).

28 Convention No. 205, 2009 (n 17). 
should be subject to similar (at least functionally similar) legal constraints and conditions as is national governance. Therefore the principle of transparency should also come to bear more on global governance as a constraint and condition of governance. Transparency should and can here fulfil functions similar to those in the domestic setting (social acceptance, legal certainty, accountability, rationalization), while the democratic rationale of transparency for international law-making is less straightforward (see on this section 11). That type of transparency might be called 'compensatory transparency' because it is intended to compensate for transparency losses that are side-effects of globalization and privatization. ${ }^{29}$ It can be understood as a manifestation of compensatory constitutionalism and multilevel governance. ${ }^{30}$

\subsection{Transparency as a Global Public Good}

Finally, transparency has become a global public good. ${ }^{31}$ The idea of global public goods (in the plural) draws on the notion of 'the' public good, but has been re-conceptualized and broadened by transferring it from the national to the global level. Global public goods in this broad sense do not necessarily qualify as pure public goods in terms of traditional economic theory, where a public good is a good that is non-rival (consumption of the good by one individual does not reduce availability of the good for consumption by others) and non-excludable (no one can be effectively excluded from using the good). ${ }^{32}$ Global public goods, as conceptualized by the United Nations Development Programme, are socially determined, not the result of market forces. They comprise rival goods which have been made (partially) exclusive, such as fish

29 Thomas Cottier/Michelangelo Temmerman, 'Transparency and Intellectual Property Protection in International Law', chapter 8 in this volume.

Anne Peters, 'Compensatory Constitutionalism: The Function and Potential of Fundamental International Norms and Structures', Leiden Journal of International Law 19 (2006), 579-610.

See the outcomes of the research programme on 'Global Public Goods' of the UN Development Programme: Inge Kaul/Pedro Conceicas (eds.), Providing Global Goods Managing Globalisation (Oxford University Press, 1999); Inge Kavl/Isabelle Gruberg Marc A. Stern (eds.), Providing Public Global Goods; International Cobelle Grunberg/ Marc A. Stern (eds.), Providing Public Global Goods: International Cooperation in the 21st Century (Oxford University Press, 2003). See also Scott Barrett, Why Cooperate? The Incentive to Supply Global Public Goods (Oxford University Press, 2010); JeanBernard Auby, La globalisation, le droit et l'Etat (Paris: L.G.D.J., 2nd edn, 2010), 174-182.

Paul A. Samuelson, 'A Pure Theory of Public Expenditure', Review of Economics and Statistics 36 (1954), 387-389. stocks; they also include nonrival goods kept or made non-exclusive, such as information. ${ }^{33}$ Global public goods in that broader sense notably comprise goods which cannot in a satisfactory manner be furnished on the national level. Besides natural or cultural resources ('common herthe national level. Besides natural or cultural reso objectives ${ }^{34}$ such as itage of mankind'), these may also be global values or objectives such as transparency. Universally acknowledged values, as explicity form in the UN General Assembly's Millennium Declaration of 2000, comprise 'good governance at the international level and (...) transparency in the financial, monetary and trading systems', and 'the right of the public to have access to information. ${ }^{35}$

\section{The Transferability of Transparency to the International Sphere}

Although international transparency may be desirable or even necessary, especially under the compensatory rationale ${ }^{36}$ it might well be unfeasible. The main problem would seem to be substantive and structural . relevant differences, and do they really prevent the application of a transparency norm?

First of all, international law has traditionally relied on regulation by First of all, international taw has traditand-control mechanisms vis-àrevelation for lack of stronger command-and-control mechanisms third-party vis sovereign States. Self-reporting, disclosure requirements, third-party monitoring, blaming and shaming, and blacklisting have been regularly applied as tools for inducing behavioural changes in States and pushing them towards compliance. Besides, the currently fashionable facting them towards compliance. Besiden, for creating transparency. All of

finding missions are specific instruments for creating tranctioned relatively smoothly. As opposed to discouraging it,

53 See Kaul et al., Providing Public Global Goods 2003 (n 31), 83, for an expanded concept of public goods, taking into account their socially determined status. The authors define public goods, taking into account the nalional public goods, i.e. the sum of national public global public goods as globalized national (ibid., 10)

34 goods plus international cooperation (180-181.

35 Auby, Latlennium Declaration, A/RES/55/2, 18 UNGA, Resolution 55/2: United Nations Millennium Declaration, A/RES/55/2, $\mathrm{V}$ : September 2000, section III: Development and Pover

Homan Rights, Democract
See above, section 3.3 .

37 These differtion whether transes and the ensuing problem of transle of international law (see below, section 16). 
this certain structure of international law would seem to accommodate a transparency principle rather well.

In the domestic sphere, along with information campaigns, the relatively new obligations imposed on business actors to label and report and have themselves monitored, audited and certified (with regard to products, their environmental impact, etc.) to some extent resemble the aforementioned traditional international legal approach The specific regulatory strategy here is an indirect market-driven regulation ('regulation through revelation', 'disclosure as governance', 'informational governance'). ${ }^{38}$ The idea is that consumers, investors, employees and other market participants who obtain these pieces of information will react with their market choices (to desist from buying a product, from investing in an enterprise, from working in a firm) and thereby pressuring the business to adapt its activity in a way that is desirable to the responsible consumer, investor, employee. Archon Fung and co-authors have called this strategy 'targeted transparency'. It resembles market-based regulation by providing choices. Both users and disclosers are free to take no action at all. The targeted entities (e.g. business) receive their signals not directly from the regulators but from the behaviour of the users themselves. Regulation by transparency is thus a distinct form of regulation. ${ }^{39}$

In the domestic sphere, the merits of this approach to regulation ('deregulate and disclose') are contested. Touted as a new mode of governance by some - as an innovative, less costly, less intrusive, more market-oriented tool - it has been criticized as toothless by others. In fact, 'informational governance' seems to function only under certain conditions and, for instance, has not prevented scandalous misbehaviour in the field of finances and securities.

In international law, the traditional reporting and disclosure requirements imposed on States bear a superficial resemblance to just that type of regulation. But there remains one crucial difference between

${ }^{38}$ See Mary Graham, Democracy by Disclosure: The Rise of Technopopulism (Washington DC: Governance Institute Brookings Institution Press, 2002); James T. Hamilton, Regulation through Revelation: The Origin, Politics, and Impacts of the Toxics Release Inventory Program (Cambridge University Press, 2005); Arthur J. P. Mol, Environmental Reform in the Information Age: The Contours of Informational Governance (Cambridge University Press, 2008); Virginia Haufler, 'Disclosure as Governance: The Extractive Industry Transparency Initiative and Resource Management in the Developing World', Global Environmental Politics 10 (2010), 53-73.

39 Archon Fung/Mary Graham/David Weil, Full Disclosure: The Perils and Promise of Transparency (Cambridge University Press, 2007), 48-49. traditional international law on 'informational' governance and the new domestic one: the 'shadow of the State', which looms behind the labelling and reporting requirements imposed by domestic law on private actors is missing on the international plane. When self-reports, public condemnations and blacklisting of States does not help to bring them into compliance with international law, stiffer enforcement mechanisms are largely lacking.

A second difference is that ever more national legal systems are acknowledging citizens' right to information - with or without a constitutional foundation. A growing number of States have an open-access policy which publication of policy which contains standard elements such as proactive pubs, and review documents on websites, procedures for granting access, and review mechanisms in the case of refusal. In contrast, international organizations generally do not acknowledge the individual rights of persons to access their documents. ${ }^{40}$ In chapter 14 , Antonios Tzanakopoulos argues that it is impossible to transpose the right to access information to the intere existence of international legal order because this would require the existence of courts with compulsory jurisdiction. ${ }^{41}$ However, the absence of compulsory judicial review would not seem to categorically exclude the application of an individual right to information to international renations. Some domestic freedom of information regimes still do organizations. Some domestablish agency-internal oversight mechanisms. That path has also been taken by the World Bank Section 17 below (p. 593) will demonstrate that the the international human right to information can also be reasonably applied to international organizations. Once this extension is accepted, you have minimized one structural difference between domestic and international law.

Third, the international legal system lacks two core constitutional features: it is not a product of direct democratic procedures (see below section 11) and the international institutions possess neither a system of section 11) and the international 'cons transferability of

${ }^{40}$ Megan Donaldson/Benedict Kingsbury, 'Power and the Public: The Nature and Effects of Formal Transparency Policies in Global Governance Institutions', chapter 19 in this volume.

1 Antonios Tzanakopoulos, 'Transparency in the Security Council', chapter 14 in this volume.

42 That is, they do not necessarily allocate the governance functions of law-making, executive action and adjudication to separate organs. 
transparency requirements to the international realm; to the contrary, it encourages it. In a State constitutional system based on the separation of powers, the tripartite system of government created by a State constitution provides for a certain amount of disclosure of government information. ${ }^{43}$ Additional transparency mechanisms are less urgent in such a setting than they are in an institutional context where the accountability mechanism inherent in the separation of powers and formal democracy is absent. As Joseph Stiglitz has pointed out: 'the less directly accountable a governmental agency is to the public, the more important it is that its actions be open and transparent. ${ }^{44}$

A final aspect is that for reasons of practicability, swiftness and uniformity, the foreign policy of even democratic States (including legal action such as treaty-making and participation in law-making within international organizations) has traditionally been entrusted to the executive branch and basically exempted from democratic and judicial oversight. The US Supreme Court justified this as follows: ' $t$ the nature of transactions with foreign nations, moreover, requires caution, and unity of design and their success frequently depends on secrecy and dispatch. ${ }^{45}$ Foreign policy has been concomitantly more intransparent than domestic policy. ${ }^{46}$

However, probably in all democratic States, there has been a clear trend towards dismantling the foreign-affairs prerogatives of the executive branch and towards more intense parliamentary involvement and tighter judicial scrutiny. The traditional 'bifurcation' between 'inward' and 'outward' action of States is eroding because interior and foreign policy (and law) can no longer be neatly distinguished ('world internal

${ }^{43}$ Antonin Scalia, 'The Freedom of Information Act Has No Clothes', AEI Journal on Government and Society, March/April (1982), 14-19, 19 criticizes the 'obsession that the first line of defense against an arbitrary executive is do-it-yourself oversight by the public

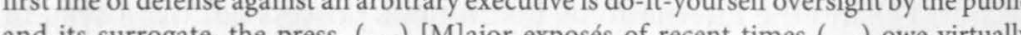
(..) nothing to the for but a primarily the product of the institutionalized check and balances within our system of representative democracy. This is not to say that public access to government information has no useful role - only that it is not the ultimate guarantee of responsible government'

${ }^{44}$ Joseph Stiglitz, 'On Liberty, the Right to Know, and Public Discourse: The Role of Transparency in Public Life', in Matthew J. Gibney, (ed.), Globalizing Rights, The Oxford Amnesty Lectures 1999 (Oxford University Press, 1999), 115-156, 155.

45 US Supreme Court, United States v. Curtiss-Wright Export Corporation, 299 US 304 (1936), 319, approvingly quoting the report of a Senate Committee on Foreign Relations from 15 February 1816 , emphasis added.

46 On the related aspect of confidentiality in diplomacy, see below section 15.1 law'). ${ }^{47}$ The blurring of the line between domestic and foreign affairs has itself undermined the possibility of neatly and reasonably distinguishing a sphere of domestic law and politics, which must be transparent, from an international sphere in which transparency seems neither feasible nor warranted 48 At the same time, the approximation of the status and furrat low and global

functions of transparency in domestic and international

To conclude, while structural and substantive differences between domestic and international law prevent a transfer of the concept of dome national to the intional level, notl specific features of international law strictly rule out its application. To the contrary, the rootedness and refinement of transparency-based compliance mechanisms facilitate the operation of an international transparency norm. And the absence of direct democratic mechanisms and a separation of powers actually underscores its usefulness and desirability. Without attempting to downplay the differences between domestic and international law and governance, it seems fair to say that inational and international transparency systems reprent variations on a single governance theme. ${ }^{49}$

\section{The Object of International Transparency: What Exactly Should Be Transparent?}

In the sphere of politics, different actors have different views as to what In the sphere of politics, different needs to be transparent. The reason is that they typically have diverging perceptions as to the relevance (salience, usability and comprehensibility) of information. ${ }^{50}$ In the context of international law and global governance, relevant information would seem to be information globeritions and the mode functioning of the transparency obligees discussed below mode or fuis Miguel Hinojosa Martínez (pp. 549-553). It is in this context that Luis Miguel Hinojosa Martinez

47 Jost Delbrück, "Prospects for a "World (Internal) Law"? Legal Developments in a Changing International System', Indiana Journal of Global Legal Studies 9 (2002), 401-431.

48 Alasdair Roberts, Blacked Out: Government Secrecy in the Information Age (Cambridge University Press, 2006), 173.

2007 (n 39), 150.

50 Gupta, 'Transparency under Scrutiny' 2008 (n 1), 5. 
has usefully distinguished between documentary, decision-making and operational transparency. ${ }^{51}$

In order to bring about meaningful global transparency, the information given must not only be relevant in the aforementioned sense but accurate and practically accessible (physically available, financially affordable, intellectually comprehensible) to the recipients. ${ }^{52}$

Transparency also requires giving reasons for action taken or not taken by the transparency-obligee. With regard to legal acts, this obligation is inherent in the rule of law because it is a precondition for any legal scrutiny of the lawfulness of the act. ${ }^{53}$ Within a framework of deliberative democracy, every policy should be not only justifiable or justified vis-à-vis specific addressees but publicly justified because ' $[\mathrm{t}$ ] he political process of justification itself shapes in several ways the nature and validity of the reasons that officials give. ${ }^{, 54}$ Here public justification appears as a proxy for rightness, justice or legitimacy. From a constructivist perspective, the right to obtain a justification has been touted as the normative core of all human rights. ${ }^{55}$

To conclude, in concrete terms, global transparency may relate to a host of activities and documents of international organizations and of other forms of inter-State cooperation. A reasonable measurement of global transparency might require that international actors maintain websites, and publish the legal acts they produce, their budget, and annual activity reports. A different matter is access to deliberations, drafts, and working documents whose publication is more than the final decisions subject to countervailing considerations, see section 15 . Through documentary, decision-making and operational transparency, the international actors' decision-making processes and the outcomes of

${ }^{51}$ Luis Miguel Hinojosa Martínez, 'Transparency in International Financial Institutions', chapter 4 in this volume.

52 See Mark Bovens, 'Information Rights: Citizenship in the Information Society', Journal of Political Philosophy 10 (2002), 317-341, 330.

53 For example, see Treaty on the Functioning of the European Union, OJ 2010 No. C83/ 47, 20 February 2010 (TFEU), art. 296(2): '[l] egal acts shall state the reasons on which they are based'; Understanding on Rules and Procedures Governing the Settlement of Disputes, 15 April 1994, 1869 UNTS 401 (DSU), art. 12(7): 'the report of a panel shall set out the (...) basic rationale behind any findings and recommendations that it makes'. ${ }^{54}$ Amy Gutmann/Denis Thompson, Democracy and Disagreement (Cambridge: Belknap, 1996), 100

${ }^{55}$ Rainer Forst, The Right to Justification: Elements of a Constructivist Theory of Justice (New York: Columbia University Press, 2011). those processes can in principle be observed, interpreted and evaluated the various items.

\section{The Obligees of Transparency: Who Is (or Should Be)} Transparent?

In international law, transparency requirements have been the classic governance tool to monitor the compliance of States with the prescripgovernance tool to monitor the rule of internations of international regimes (multilatera tional organizations, soft standards). This book mainly examines the transparency of States as induced by international law in those chapters addressing environmental matters (chapter 2 by Jutta Brunnée and Ellen Hey, chapter 3 by Jonas Ebbesson), international taxation (Chapter 7 by (Chapter 10 by Cosette Creamer and Beth A. Simmons), warfare (Chapter 13 by Orna Ben-Naftali and Roy Peled) and non-proliferation (Chapter 15 by Mirko Sossai).

A different question is the transparency of international organizations. A standard textbook on international organizations summarizes the trend: '[s] ince the 1990 s, international organizations have increasingly accepted the need to make their decisions as transparent as possible and to ffer the general public as much access as possible to information concerning the work of the organization. ${ }^{56}$ This phenomenon is examined in detail in the chapters on international financial institutions (chapter 4 by Luis Miguel Hinojosa Martínez), the WTO (chapter 5 by Panagiotis Delimatsis), the WHO (chapter 11 by Emily Bruemmer and Allyn Taylor), the UN Security Council (chapter 14 by Antonios Allon (chapter 17 by Thore Neumann and Bruno Simma) and more generally in the chapter on global governance institutions (chapter 19 by Megan Donaldson and Benedict Kingsbury).

No specific chapter is devoted to the $\mathrm{EU}$, whose transparency rules meanwhile resemble a full-fledged domestic regime. Since 1992, article of the Treaty on European Union (TEU) speaks of a Union 'in which decisions are taken as openly as possible', and the European White Paper on Governance (2001) highlighted 'open governance' as a major

${ }^{56}$ Henry G. Schermers/Niels M. Blokker, International Institutional Law (Dordrecht: Martinus Nijhoff, 5th edn, 2011), 255. 
principle of governance. ${ }^{57}$ Several novel provisions were enshrined in the 2007 Lisbon Treat ${ }^{58}$ in order to make Union governance more open and transparent. Under article 10(3) TEU '[d]ecisions shall be taken as openly and as closely as possible to the citizen.' Article 11 TEU reads: '1. The institutions shall, by appropriate means, give citizens and representative associations the opportunity to make known and publicly exchange their views in all areas of Union action. 2. The institutions shall maintain an open, transparent and regular dialogue with representative associations and civil society. 3. The European Commission shall carry out broad consultations with parties concerned in order to ensure that the Union's actions are coherent and transparent. ${ }^{59}$ The new and comprehensive article 15 of the Treaty on the Functioning of the European Union (TFEU) foresees public legislative proceedings and access to documents. ${ }^{60}$ Moreover, the individual and general right of access to documents has the status of a fundamental European right (article 42 Charter of Fundamental Rights). The EU Transparency Regulation spells out the conditions of that right. ${ }^{61}$ All legal acts must give reasons (article 296 TFEU) and all legal acts must be published in the Official Journal (article 297 TFEU and article 13 of the Transparency Directive). These detailed and far-reaching transparency rules, which have been basically established and expanded in only the past twenty years, demonstrate how far a supra-State transparency regime can advance. However, despite these reforms, criticism about a

${ }^{57}$ EU, European Commission, European Governance: A White Paper, COM(2001) 428 final, 25 July 2001 , section II.

58 Treaty of Lisbon amending the Treaty on European Union and the Treaty Establishing the European Community, OJ 2007 No. C306/01, 17 December 2007.

${ }^{59}$ Emphasis added.

${ }^{60}$ TFEU, 2010 (n 53), art. 15: '1. In order to promote good governance and ensure the participation of civil society, the Union institutions, bodies, offices and agencies shall conduct their work as openly as possible. 2 . The European Parliament shall meet in public as shall the Council when considering and voting on a draft legislative act. 3 . Any citizen of the Union, and any natural or legal person residing or having its registered office in Member State, shall have a right of access to documents of the Union institutiod office in Member State, shall have a right of access to documents of the Union institutions, bodies, offices and agencies, whatever their medium, subject to the principles and the conditions
to be defined in accordance with this paragraph' (emphasis added). to be defined in accordance with this paragraph' (emphasis added).

EU, Regulation (EC) No. 1049/2001 of the European Parliament and of the Council of 30 May 2001 Regarding Public Access to Documents, OJ 2001 No. L145/43, 31 May 2001 (EU Transparency Regulation). See Frank Riemann, Die Transparenz der Europäischen Union: Das neue Recht auf Zugang zu Dokumenten von Parlament, Rat und Kommission (Berlin: Duncker \& Humblot, 2004). lack of 'real' transparency, especially regarding the higher levels of EU policy-making, seems to persist.

Between the obligees of transparency and the beneficiaries (see below

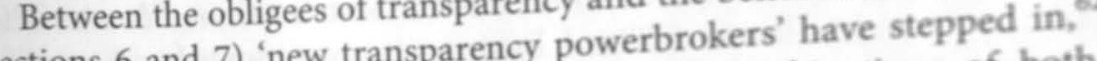
sections 6 and 7) 'new transparency powerorokers' have steps of both. notably NGOs, commercial enterprises, and combinations of the task These brokers verify, certify, audit and distribute information. The task is for these actors to become more transparent as well. In fact, specific NGOs - but also NGOs as a whole, traditionally the 'good guys' in global governance - are increasingly facing the critique of being unrepresentstive, undemocratic, or not sufficiently independent from governments or interest groups. They too have a legitimacy problem and enact transparency policies to counter reproaches to the contrary. ${ }^{63}$ While this book does not contain a specific chapter on NGOs, their relative intranspar

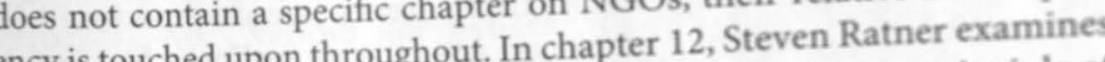
ency is touched upon throughout. identity is constituted by its principle of the ICRC, a unique $\mathrm{NGO}$ wh.
secrecy and confidentiality ${ }^{64}$

A difficult question is to what extent transparency requirements can A difficult question is to private, notably economic actors. In any be legitime rule of law, these actors are in a fundamentally

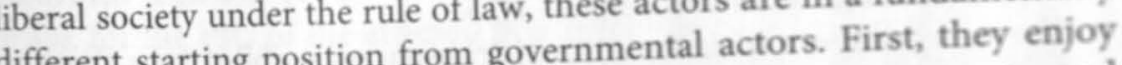
different starting position from govern right to privacy, property and liberty, inclesting business secrecy. In contrast, States and inter-governific competencies.

62 Arthur P.J. Mol, 'The Future of Transparency: Power, Pitfalls and Promises', Globual Arthur P. J. Mol, 'The Future of Transparency: Power, Pitfalls and Promises', Globul Environmental Politics 10 (2010), 132-143, 139. On the need for "intermediaries' so that transparency might have an impact, see Megan Donaldson/Benedict Kingsbury, Powct and the Public: The Nature and Effects of Formal

Governance Institutions', Chapter 19 in this volume.

3 On the transparency of NGOs as a component of their legitimacy and accountability, seet Hetty Kovach/Caroline Nelligan/Simon Burall, The Global Accountability Report: Power without Accountability? (London: One World Trust, 2003), 21-28 and 33; Anton Vedder (ed.), The Involvement of NGOs in International Governance and Policy: Sources of Legitimacy (Leiden: Martinus Nijhoff, 2007); Monica Blagescu/Robert Loyd, 'Accountability of Transnational Actors: Is There Scope for Cross-sector Principles?', in Anne Peters et al. (eds.), Non-State Actors as Standard Setters (Cambridge University Press, 2009), 270-303; Anne Peters, 'Members of the Constitutional Community', in Jan Klabbers/Anne Peters/Geir Ulfstein, The Constitutionalization of International Lan (Oxford University Press, 2011), 153-262, 236-237. For a domestic perspective, seet Nicolás University Nicolas Cobo Rontificia Universidad Católica de Chile, 2012), 73-99.

${ }_{64}$ Católica de Chile, 2012),73-99. International Committee of the Red Cross', chapter 12 in this volume. 
Second, business actors pursue activities in their own interest, their primary role being to make money and generate welfare by providing goods and employment; in contrast, it is the State's raison d'être to fulfil tasks in the public interest. Third, business is not endowed with specific powers which resemble State powers, namely the power to unilaterally enact law which is formally binding on natural persons who have not (at least not directly) consented to it, and the institutional and physical means to enforce it (police, courts, bailiffs).

The special case of actors established in legal forms provided by domestic private law (shareholder companies, anonymous societies, and the like) but entrusted with the performance of public functions (tasks in the interest of the general public) has already been discussed under the heading of compensatory transparency (see above section 3.3). Beyond those quasi-public economic actors, even ordinary business is increasingly facing societal expectations to satisfy certain 'public' standards, including transparency requirements. Chapter 18 by Larry Catà Backer deals with these business actors. The human rights issue as to whether the fundamental right to information is opposable to business actors is discussed below in section 17.3.

The new obligees of international transparency obligations (besides States) manifest a novel functionality of transparency in the international legal system. 'Transparency for governance' has been supplemented by 'transparency of governance', to rely on a distinction made by Ronald Mitchell. ${ }^{65}$ Transparency for governance entails those policies and institutions designed to alter the behaviour of the regulatees. Under international law, these are mainly the individual States which are supposed to be brought into compliance (through monitoring, selfreporting, etc.). In contrast, 'transparency of governance' is those policies and institutions designed to empower a polity (in our case, a global citizenry) to observe the actions of the 'regulators'. In international law the regulators are those States acting collectively by adopting treaties and collaborating within treaty regimes and organizations as well as those international organizations which issue secondary law and take measures. The new 'global transparency' signifies an extension from

${ }^{65}$ Jutta Brunnée/Ellen Hey, 'Transparency and International Environmental Institutions', Chapter 2 in this volume, relying on Ronald B. Mitchell, 'Transparency for Governance: The Mechanisms and Effectiveness of Disclosure-based and Education-based Transparency Policies', Ecological Economics 70 (2011), 1882-1890, 1882. transparency for governance only to transparency of global governance itself as well.

\section{The Beneficiaries of Transparency: Who Should Obtain Information?}

Because transparency is always relational, it matters who is and who should be the rightful recipient of a relevant piece of information. In should be the rightful recipient of a relevant piece of information. In classic inter-State law, the international transparency obligations have benefited States. For example, in disarmament law (chapter 15) the legal schemes are designed to ensure that information on arms is made available to other States but not to the general public (including potential terrorists). Also, various international environmental regimes require exporting States or export firms operating under the jurisdiction of a State party to make certain information about a traded product (e.g. State party to make certain information about a traded proste) available to importing genetically modified organisms, hazardous waste) available to importior States so as to obtain from the importing State the latter's prior to ask for the PIC of the affected populations.

The various chapters of this book reveal that the legal beneficiaries of The various chapters of this book reveal that the legal beneficiaries of transparency depend on the areas of international law. The circle of
beneficiaries of transparency would seem to be expanding, for pure interState transparency is increasingly being seen as insufficient. On top of traditional transparency, societal actors are asking for transparency vis-à-vis themselves, and the international institutions to a certain extent respond. Individuals as transparency beneficiaries are most prominent in the field of international adjudication. Courts and tribunals regularly communicate with individuals without any mediation through States. Individuals are in the direct focus of international rules and practices on judicial transparency. ${ }^{67}$ This development might well evidence a growing perception that the ultimate constituency of international law and politics is human beings and that these form a nascent global civil society and this apart from being organized into nation-States. We have a positive feedback loop here because granting more information to the general public in turn helps to constitute such an (imagined) global civil

6 Jutta Brunnée/Ellen Hey, 'Transparency and International Environmental Institutions', chapter 2 in this volume with further references.

67 Thore Neumann/Bruno Simma, 'Transparency in International Adjudication', chapter 17 in this volume. 
society. NGOs symbolize just such a global civil society but do not in any formal sense represent a global citizenry ${ }^{68}$ Besides informing NGOs, international organizations and regimes should also grant more information to and thereby become more transparent vis-à-vis domestic parliaments (not only towards the executive branches of States), who form important links to citizens. ${ }^{69}$

\section{Transparency as a Power Shifter}

The emergence of international transparency as principle and practice is both a result and a promoter of shifts in power and perceptions of legitimacy. Working on the truism that 'knowledge itself is a power' (Francis Bacon), ${ }^{70}$ governments have traditionally attempted to guard the arcana imperii. ${ }^{11}$ Raison d'état dictated the keeping of State secrets and leaving neighbours (notably 'foes') in ignorance as to the ruler's plans and projects. Intransparency has long been an accomplice of statecraft. Consisting of a professional bureaucracy, the modern State preserved this ally in the form of the Amtsgeheimnis ('office secret'). According to Max Weber, the '[b]ureaucratic administration always tends to exclude the public, to hide its knowledge and its action from criticism as well as it can. (...) The pure power interests of bureaucracy exert their effects far beyond [the] areas of functionally motivated secrecy. The concept of the "office secret" is the specific invention of bureaucracy and few things it defends so fanatically as this attitude. ${ }^{, 72}$ In that early phase of international organizations, namely the Cold War era, the international legal scholar Paul Reuter espoused similar reasoning

${ }^{68}$ Anne Peters, 'Dual Democracy', in Klabbers/Peters/Ulfstein, Constitutionalization 2011 (n 63), 263-341, 315-318. For the need to distinguish between the transparency of international organizations with respect to the general public and towards NGOs, see Grigorescu, 'Transparency of Intergovernmental Organizations' 2007 (n 7), 641.

${ }^{69}$ For transparency vis-à-vis domestic parliaments, see Allen Buchanan/Robert O. Keohane, 'The Legitimacy of Global Governance Institutions', Ethics and International Affairs 20 (2006), 405-437, 431.

Francis Bacon, Mediationes Sacrae (1597), ch. 11: Of Heresies, M4 (with regard to 71 God).

'Take away a government's preserve on information, and its preserve on when and what to release, and take away a fundamental bulwark of its power'. Birkinshaw, Freedom of 72 Information 2010 (n 10), 30.

Max Weber/Guenther Roth/Claus Wittich (eds.), Economy and Society, vol. 3 (New York: Bedminster Press, 1968), ch. XI: Bureacracy, section 11B (Administrative Secrecy), with regard to organizations that commanded global reach. For him, organizations needed to preserve an inner sphere of secrecy in order to preserve their autonomy from the member States, and thus their political power. $^{73}$

The problem is the mix of political power combined with intransparency of the bases of that power: '[j] ust as secrecy protects (...) abuses of power, so it also gives those who employ it successfully more power, thus increasing their susceptibility to corruption, and in turn a still greater need for secrecy. ${ }^{74}$ Transparency tries to break this vicious circle, thus functioning as a power-shifter, as 'emancipatory transparency. Transparency empowers outsiders because it equips them with information and thereby creates a precondition for holding power-holders to account.

However, transparency does not empower all stakeholders to an equal extent. Rather, more transparency leads to a power shift from those actors who know the right people to those who possess the know-how actors who know the right people the and resources to collect, analyze and interpret the data. On average, the political actors of the First World (above all States, but also NGOs and businesses) can better exploit the opportunities for influence that are created by improving (international) transparency ${ }^{76}$ Legal observers should not only acknowledge that 'the battle for transparency' is a struggle for power" 'struggle for power'

'Power and the Public: The Nature and Effects of Formal Transparency Policies in Global Governance Institutions', chapter 19 in this volume, analyzing Paul Reuter, 'Le droit au secret et les institutions internationales', Annuaire francais de droit international 2 (1956), 46-65, 61. Reuter relied on the institutional theory of international organizations, thus conceding them a 'proper life', institutional theory of intertite for individuals as well as for and drew an analogy between

${ }^{24}$ social groups and institutions.

74 Sissela Bok, Secrets (New York: Pantheon, 1982), 106.

$76 \mathrm{Mol}$, 'The Future of Transparency' 2010 (n 62), 135-136. Megan Donaldson/Benedict Kingsbury, 'Power and the Public. The Nature and 19 in this of Formal Transparency Policies in Global Governance institutions', chapter volume. See also Kristin M. Lord, The Perils and Promise of Global Try, or Peace (Albany: the Information Revolution May Not Lead to Security, Democracy, or Pecrecy 2006 (n State University of New York Press, 2006 )

48), 194-195.
7 Ann Florini, 'Conclusions', in Ann Florini (ed.), The Right to Know: Transparency for an Open World (New York: Columbia University Press, 2007), 348. 


\section{Transparency and Shifting Perceptions of Legitimacy}

While the exercise of political power has always needed legitimacy (being accepted by those who are governed and deserving that acceptance) for its sustenance, throughout history the traditional relationship between transparency and legitimacy has been reversed. In the early days of statehood it was exactly the intransparency of governance which constituted a source of (religious or quasi-religious) legitimacy for the rulers. ${ }^{78}$ Secrecy constituted the 'mystery' (arcana-mysteria) of the State. An aura of sacredness surrounded the State, just as it did the church. ${ }^{79}$ Up to the eighteenth century, the intransparency of the State was deemed a perfectly legitimate and even necessary component of governance. The terms for political offices such as 'secretary of state' (derived from Latin secretum, meaning 'secret') or Geheimrat (in German, Geheimnis likewise means 'secret') manifest this outlook. ${ }^{80}$

With the onset of the Enlightenment, philosophers began to denounce State secrecy, though not necessarily in a liberal spirit. ${ }^{81}$ In his essay 'On Publicity' (1790), Jeremy Bentham declared that 'Secrecy is an instrument of conspiracy; it ought not, therefore, to be the system of a regular government. ${ }^{82}$ Jean-Jacques Rousseau suggested that all citizens be "constantly under the public eye ${ }^{, 83}$ and that office-holders should wear a uniform so that they could never be anonymous as they went about their daily lives. ${ }^{84}$ Such projects of surveillance were ultimately totalitarian. ${ }^{85}$

${ }_{78}^{78}$ Bok, Secrets 1982 (n 74), 172-173.

79 Ernst H. Kantorowicz, 'Mysteries of the State: An Absolutist Concept and Its Late Mediaeval Origins', Harvard Theological Review 48 (1955), 65-91. Mystery also had the meaning of 'prerogative', or 'handicraft', of kings (ibid., 68). On the parallel between church secrecy (arcana ecclesiae) and State secrecy (arcana imperii), see Bok, Secrets 1982 (n 74), 172.

${ }^{80}$ Lucian Hölscher, Öffentlichkeit und Geheimnis: Eine begriffsgeschichtliche Untersuchung zur Entstehung der Öffentlichkeit in der frühen Neuzeit (Stuttgart: Klett-Cotta, 1979), 7.

${ }^{81}$ See Michel Foucault, 'L'oeil du pouvoir', in Michel Foucault, Dits et ecrits II, 1976-1988 (Paris: Gallimard, 2001), 190-207. On Foucault see also Orna Ben-Naftali/Roy Peled, 'How Much Secrecy Does Warfare Need?', chapter 13 in this volume.

82 Jeremy Bentham, 'On Publicity', in Michael James/Cyprian Blamires/Catherine PeaseWatkin (eds.), The Collected Works of Jeremy Bentham: Political Tactics (Oxford: Clarendon, 2001), 39.

83 Jean-Jacques Rousseau, The Government of Poland (Willmoore Kendall trans.) (Indianapolis: Hackett, 1985), ch. XII: The Military System.

${ }^{84}$ Ibid., ch. XIII: Plan for a Sequence of Official Promotions Embracing All Members of the Government.

85 Critically on Benthamite surveillance Michel Foucault, Discipline and Punish: The Birth of the Prison (Alan M. Sheridan trans.) (New York: Pantheon Books, 1977).
In his Perpetual Peace (1795), ${ }^{86}$ if only as a thought experiment, Immanuel Kant used transparency (Publicität) as a test of legitimacy: '[a]ll actions affecting the rights of other human beings are contrary to right and law if their maxim is not compatible with their being made public. ${ }^{87}$ For John Stuart Mill, publicity (transparency) was beneficial because it can 'compel deliberation and force everyone to determine, before he acts, what he shall say if called to account for his actions. ${ }^{, 88}$ Such reflections have generated the perception that government secrecy is not proper as such but rather suspect; intransparency no longer lends legitimacy to political institutions but undermines it.

The interdependency between transparency, power and legitimacy implies that once political power is exercised by international organizations, they then face similar challenges as States. In order to prevent the corruption of that power and acquire legitimacy, they need to become (more) transparent. It is therefore hardly surprising that those international organizations which first experienced legitimacy crises - notably the $\mathrm{EU}^{89}$ and international financial institutions in the 1980 s and $1990 s^{90}$ - reacted by enacting transparency measures. The legitimacy pressure ${ }^{91}$ on these organizations led to the introduction of transparency policies in order to regain (or feign) legitimacy. The relatively novel international criminal courts and tribunals face specific legitimacy problems as well. Their existence and judgments are often contested by certain groups in post-conflict societies. This explains why these courts

${ }^{86}$ Immanuel Kant, Zum ewigen Frieden (Stuttgart: Reclam, 1984), appendix II: Von der Einhelligkeit der Politik mit der Moral nach dem transcendentalen Begriffe des öffentlichen Rechts: 'Alle auf das Recht anderer Menschen bezogene Handlungen, deren Maxime sich nicht mit der Publicität verträgt, sind unrecht'.

87 Ibid., 'ein Experiment der reinen Vernunft'.

88 John Stuart Mill, Considerations on Representative Government (South Bend: Gateway, 1962), 214.

${ }^{89}$ See above: section 5, text with nn 57-61.

90 Thomas Blanton, 'The Struggle for Openness in the International Financial Institutions', in Florini (ed.), Right to Know 2007 (n 77), 243-278. See also the 2005 study on public access to information undertaken by seven financial and national institutions in five different countries by Catherine Musuva (ed.), Behind Closed Doors: Secrecy in International Financial Institutions (Cape Town: Institute for Democracy in South Africa and the Global Transparency Initiative, 2006). The results showed a 'generally high level of opacity surrounding the disclosure of information related to IFIs' (ibid., vi).

91 Philipp Dann, 'Der Zugang zu Dokumenten im Recht der Weltbank: Kosmopolitische Tendenzen im Internationalen Verwaltungsrecht?', Die Verwaltung 22 (2011), 313-325, 316. 
and tribunals typically engage in outreach policies which seek to render clear and understandable their activity to the populations concerned. ${ }^{92}$

Notably the World Bank and the WTO have compelled member States or aid-recipients to establish transparency policies. These organizations have spawned the criticism that while pressuring their clients to become more transparent they have remained intransparent themselves. ${ }^{93}$ The organizations were thus compelled to abandon that self-contradictory stance so as to become credible. For example, in 2010 the World Bank introduced a Policy on Access to Information, ${ }^{94}$ which has been called a 'small revolution'. 95

\section{The Value and Functions of Transparency}

Transparency has both an instrumental and an intrinsic value. It is a tool to support performance and increase the rationality and accountability of governance, but at the same time it is bound up with values such as democracy, rule of law, integrity and trust. The positive connotations of transparency do not warrant a naïve belief in 'the catalytic power of disclosure (...) [that] if only the facts were made public, justice would follow. ${ }^{, 96}$ However, the commitment to transparency manifests normative convictions, and voluntary transparency sends a political signal about these. $^{97}$ One question of this book is whether the value and functions of governmental transparency also justify international transparency.

\subsection{In Domestic Law and Governance}

In order to answer that question, we must first briefly recapitulate the objectives of 'domestic' transparency. These are enumerated in the preamble of the Council of Europe Convention on Access to Official Documents (No. 205) of 2009. This Convention is a good starting point

92 Thore Neumann/Bruno Simma, 'Transparency in International Adjudication', chapte 17 in this volume.

${ }^{93}$ On this aspect, in particular see Panagiotis Delimatsis, 'Institutional Transparency in the WTO', chapter 5 in this volume.

${ }^{94}$ WB, 'World Bank Policy on Access to Information', 1 July 2010, http://documents. worldbank.org.

95 Dann, 'Recht der Weltbank' 2011 (n 91), 313-325, 313.

${ }_{97}$ Roberts, Government Secrecy 2006 (n 48), 232.

${ }^{77}$ Lord, Global Transparency 2006 (n 76), 17. because it encapsulates an international consensus on the merits of transparency ${ }^{98}$ ' $[\mathrm{c}]$ onsidering the importance in a pluralistic, democratic society of transparency of public authorities; considering that exercise of a right to access to official documents: (i) provides a source of information for the public; (ii) helps the public to form an opinion on the State of society and on public authorities; (iii) fosters the integrity, efficiency, effectiveness and accountability of public authorities, so helping affirm their legitimacy (...). ${ }^{99}$ Let us look at the key terms one by one. First, Convention No. 205 evokes a democratic society and mentions accountability. The explanatory reports spells this out: ' $\mathrm{t}$ ] ransparency of public authorities is (..) an indicator of whether or not a society is genuinely democratic and pluralist, opposed to all forms of corruption, capable of criticising those who govern it, and open to enlightened participation of citizens in matters of public interest. ${ }^{, 00}$ The links between transparency and democracy as well as to accountability will be discussed below (sections 11 and 12).

Second, Convention No. 205 speaks of official documents as a source of information and a means to forming an opinion. Indeed, the lack of information, like any form of artificially created scarcity, gives rise to rents. For example, politicians can exploit their control of information to reward media persons by confidential disclosures, and this may also be used by those same politicians to distort that information. ${ }^{101}$ Transparency can counteract this phenomenon.

Third, Convention No. 205 seeks to improve the integrity, efficiency and effectiveness of public authorities. In fact, intransparency provides the opportunity for specially interested groups to exercise greater sway since these groups will offer rewards to office-holders for granting them since these groups will offer rewards to office-holders for granting them creates a conflict of interest for the office-holder and risks undermining the office-holders' integrity. ${ }^{103}$ Needless to say, bribery and corruption are not in the public interest. Also, so as to maintain secrecy, the circle of

98 Convention No. 205, 2009 (n 17). The Convention is not yet in force, but no principled obstacle seems to prevent the attainment of a sufficient number of ratifications.

99 Ibid., preamble.

100 Ibid., explanatory report, in the commentary on the preamble, para. 1.

${ }^{101}$ Stiglitz, 'On Liberty' 1999 (n 44), 133-134. ${ }^{102}$ Ibid., 132-33.

103 For a general tranters Glabal, Public and Corporate Governance (Cambridge University Press, 2012). 
those involved in decision-making is greatly circumscribed, which weakens the quality of decision-making. ${ }^{104}$

Fourth, the Convention's explanatory report points out that '[t]ransparency of public authorities is a key feature of good governance' ${ }^{105}$ Fifth, the Convention's explanatory report states that '[t]he right of access to official documents is also essential to the selfdevelopment of people and to the exercise of fundamental human rights.' Indeed, governmental transparency is to some extent a question of social justice because it is a precondition for the meaningful exercise of both political and social rights. Without access to governmental information, the citizens' capacity to make rational choices and to draw up a rational life-plan is seriously hampered. ${ }^{106}$ Along these lines, the Indian right-to-information campaign used the slogan: ' $t$ the right to know is the right to live. ${ }^{107}$ Based on all those considerations, the Convention's preamble concludes that 'all official documents are in principle public'.

\subsection{In International Law and Governance}

The book identifies similar rationales of transparency at work in international law and for purposes of global governance as in the domestic sphere. It is here too that the cluster of functions relating to accountability, participation and democracy is to the fore. For example, in international environment law, Jonas Ebbesson finds that transparency is seen as a precondition for the effective participation of civil society actors in environmental governance. ${ }^{108}$ In the area of disarmament and non-proliferation, according to Mirko Sossai, the involvement of NGOs in the 'de facto monitoring' of the relevant international treaties displays 'dynamic reasons for transparency: the aim is not only that of building

104 Stiglitz, 'On Liberty' 1999 (n 44), 137. See also the UK, Your Right to Know: Freedom of Information, Cm 3818, December 1997, para. 1.1: '[U]nnecessary secrecy in government leads to arrogance in governance and defective decision making'.

105 Convention No. 205, 2009 (n 17), explanatory report, commentary on the preamble, para. 1 (emphasis added).

106 Bovens, 'Information Rights' 2002 (n 52), 326.

107 Shekar Singh, 'India: Grassroots Initiatives', in Florini (ed.), Right to Know 2007 (n 77), 19-53.

${ }^{108}$ Jonas Ebbesson, 'Global or European Only?: International Law on Transparency in Environmental Matters for Members of the Public', chapter 3 in this volume. confidence among States parties but also of encouraging democratic oversight and public scrutiny. ${ }^{, 109}$

As in domestic bureaucracies, transparency is sought to maintain the integrity of the international administrations and prevent conflict of interest. Thomas Cottier and Michelangelo Temmerman relate how transparency reforms in the WIPO have been employed in reaction to an institutional crisis that was triggered by bad management and which led to biased recruitment and political favouritism. ${ }^{110}$

Good governance - notably in the form of the previsibility of a legal setting as well as legal certainty - is vital for economic actors and their business decisions, for instance for investors. These considerations have motivated transparency requirements in international investment law. Julie Maupin points out that transparency is a core component of the treaty-based fair and equitable treatment standard relating to the content of laws and regulations introduced by the host State. ${ }^{111}$

Third, transparency is also introduced in order to further the effectiveness and efficiency of international legal regimes. The welfare arguments in favour of transparency and information-sharing have been mostly raised in the financial sector, first with regard to the ordinary market participants and then with regard to the World Bank itself. It has been empirically shown (though a direct causal relationship has been difficult to establish) that a financial crisis is more likely when financial liberalization takes place in the absence of transparency. ${ }^{112}$ Luis Miguel Hinojosa Martínez explains that transparency is valuable for the World Bank as a developmental institution 'because the design and implementation of its policies will receive input from local communities that will tation of its policies will receive input from local comm the field and thus make its projects better adapted to the conditions in the field and thus more effective. 113

109 Mirko Sossai, 'Transparency as a Cornerstone of Disarmament and Non-proliferation

110 Regimes', chapter 15 in this volume. Protection in International Law', chapter 8 in this volume.

111 Julie Maupin, 'Transparency in International Investment Law: The Good, the Bad and the Murky', chapter 6 in this volume.

112 Tara Vishwanath/Daniel Kaufmann, 'Toward Transparency: New Approaches and Their Application to Financial Markets', The World Bank Research Observer 16 (2001) markets to the access to information.

113 Luis Miguel Hinojosa Martínez, 'Transparency in International Financial Institutions', chapter 4 in this volume. 
On the other hand, some aspects of transparency seem peculiar to international law. For example, in a landscape of 'proliferated' and disconnected international courts and tribunals, the admission of individual judicial opinions can perform a beneficial systemic function by allowing a court (which wants to decide a legal question in a way different from other courts or tribunals) to refer to pre-existing dissenting opinions. An international judge or arbitrator thereby enters into a judicial dialogue instead of silently treading their own path. Such references are apt to strengthen the overall coherence of international law by demonstrating that the legal solution was already in the system. ${ }^{114}$

Finally, there are areas of international law in which transparency seems less needed than in the domestic sphere. For example, as Steven Ratner shows, the credibility of the International Committee of the Red Cross (ICRC) has not been undermined by its intransparency. On the contrary, the ICRC's credibility has been enhanced. The fact that the organization gives the assurance to warring parties that it will not publicize what it sees, e.g. in detention centres, helps persuade those parties to allow access to such sites, and thus generally allows the ICRC to fulfil its role as a guardian of international humanitarian law. ${ }^{115}$ However, differences in the functionality of transparency at the domestic and international levels are mitigated by the fact that obviously the various goals of transparency are not necessarily always in alignment with each other and that their importance may vary depending on time and context and on all levels of governance.

\section{Transparency and Democracy: Domestic and International}

Democracy needs transparency. The classic statement in this regard was tendered by James Madison: '[A] popular Government, without popular information, or the means of acquiring it, is but a prologue to a Farce or a Tragedy; or perhaps both. Knowledge will forever govern ignorance: [A]nd a people who mean to be their own Governors must arm themselves with the power which knowledge gives. ${ }^{116}$ Transparency is

114 Observation by Thore Neumann.

115 Steven Ratner, 'Behind the Flag of Dunant: Secrecy and the Compliance Mission of the International Committee of the Red Cross', chapter 12 in this volume.

116 James Madison, 'James Madison to W. T. Barry', in Philip B. Kurland/Ralph Lerner (eds). The Founder's Constitution (University of Chicago Press, 1987), ch. 18, docu(eds.), The Founder's C03-109. This remark was made in the context of establish State-funded educational system (I thank Roy Peled for this information). obviously a conditio sine qua non for the informed consent of the governed. It is critical for uncovering abuses and defending interests. Transparency facilitates control and scrutiny. It allows the addressees of (national or international) norms and decisions as well as the public at large to evaluate the rationality of measures and to assess whether there is a legitimate aim behind them. Transparency may thus protect against both illegality, and overreaching and self-dealing, by governing actors. Furthermore, transparency is apt to encourage public participation. Those who are uninformed are not induced to participate actively, thus leaving the field to groups with special interests and distorting democratic processes. ${ }^{117}$ Finally, intransparency gives political incumbents a distinct advantage over their political rivals in democratic processes and thereby prevents democratic renewal.

The democratic rationale of transparency as just sketched out figures prominently in most international hard and soft rules prescribing domestic transparency for States. ${ }^{118}$ In an important case, the InterAmerican Court of Human Rights described the positive-feedback loop between transparency and access to information on the one hand, and democratic control on the other: '[D]emocratic control by society, through public opinion, fosters transparency in State activities and promotes the accountability of State officials in relation to their public activities. Hence, for the individual to be able to exercise democratic control, the State must guarantee access to the information of public interest that it holds. By permitting the exercise of this democratic control, the State encourages greater participation by the individual in the interests of society.' ${ }^{119}$

In the absence of formal representation of a global citizenry, elections to a global parliament, and voting on global political affairs, international law and governance is not currently democratic in the traditional

117 Stiglitz, 'On Liberty' 1999 (n 44), 135-136; Panagiotis Delimatsis, 'Institutional Transparency in the WTO', chapter 5 in this volume, with regard to participation in WTO activities.

118 For instance, see the Convention No. 205, 2009 (n 17), preamble; OAS, Inter-American Demontic Democratic Charter (Declaration 2001, art. 4; OAS, General Assembly, Access to Public Information. Strengthening Democracy, AG/RES. 2252 (XXXVI-O/06), 6 June 2006; UN, ECOSdendum: Lucca Commission for Europe, Report of the First Meeting of the

119 Declaration, ECE/MP.PP/2/Add.1, 2 April 2004, para. 2.
IACtHR, Case of Claude Reyes et al. v. Chile, Judgment of 19 September 2006, 2006 Series C No. 151, para. 87 (emphasis added). 
sense of democracy within a nation-State; ${ }^{120}$ however, the international legal system might have a proto-democratic quality in which transparency plays a role. Any assessment of this matter must proceed from the real state of contemporary democratic life, not from any unattainable ideal, and observers and reformers should be prepared to accept new types of democracy without diluting the concept of democracy too much. With these two considerations in mind, the question is whether and how transparency can become democratically relevant for international actors.

I submit that transparency can alleviate the democratic deficit to be found in both international organizations and international law-making processes. ${ }^{121}$ Transparency is 'crucial to providing a reasonable semblance of democracy at the global level of decision making'; ${ }^{122}$ in other words, it is a constitutive element of a new kind of global democracy. Transparency is clearly no full substitute for formal democratic processes allowing global citizens to vote for international rules and elect the officials of international institutions; however, it can work for more democratic control and greater accountability. With regard to the IMF and the World Bank, Joseph E. Stiglitz opined: '[W]hen direct democratic accountability is lacking, alternative accountability mechanisms must be sought. Of these, openness and transparency are the most important. ${ }^{123}$

Another interesting aspect is the relationship between the parliamentarization of international organizations and their degree of transparency. Empirical research found that when parliamentarians are involved in the decision-making of an international organization such as the $\mathrm{EU}$, the governments of the member States will be ready to release

${ }_{121}^{120}$ Peters, 'Dual Democracy' 2011 (n 68), 263-341.

${ }^{121}$ For a pioneering work on international democracy and international transparency, see Ann Florini, The Coming Democracy: New Rules for Running a New World (Washington DC: Island Press, 2003). See also Hale, 'Transparency, Accountability and Global Governance' 2008 (n 8), 73-94, 73 and 91.

122 Florini, Coming Democracy 2003 (n 121), 207.

123 Joseph E. Stiglitz, 'Democratizing the International Monetary Fund and the World Bank: Governance and Accountability', Governance 16 (2003), 111-139, 133. Stiglitz continues: '[I]t is not just that they are fundamental to democratic processes. Public scrutiny will put a check on the most abusive practices. It can increase the likelihood that the policies that are in the gestabusive practices. It can increase the likelihood the financial community - the gecial interest of, say, the financial comment no less than democratic governments, should be subjected to Freedom of Information
acts' (ibid., 133). information - probably because they know that the public will receive that information anyway through the parliamentarians. ${ }^{124}$ We thus find a positive-feedback loop here as well - while more transparency is a precondition for democracy, more democracy in the form of involving parliaments will in turn increase an organization's transparency.

Theories of deliberation and reflexive democracy are apt to underscore the importance of transparency for democracy and serve as guidelines for reform. Amy Gutman's and Denis Thompson's book on deliberative democracy contains a chapter entitled 'The Value of Publicity'. ${ }^{125}$ The authors write: '[t]he reasons that officials and citizens give to justify political actions, and the information necessary to assess those reasons, should be public. This principle of publicity is a fundamental requirement of deliberative democracy. ${ }^{, 26}$ It is from this perspective that the 'deliberative' and 'participatory' process of reason-giving, of deliberation itself, shapes the objective and to some extent defines the legitimacy of the policy and thus furnishes a type of procedural legitimacy to the measures. Although this strand of thought focuses on 'publicity' rather than on transparency, the basic idea applies: transparency (just like publicity) contributes 'to the desirability of the policy itself.' ${ }^{127}$ Transparency (like publicity) gives citizens not only the opportunity to decide for themselves on the merits of the reasoning that led to the policy, but also improves their chances of understanding the reasoning that led to the policy; if not, citizens 'remain disconnected'. ${ }^{128}$

It has also been pointed out that political debate today has become far more reflexive, i.e. that the word of public authorities and scientists is no longer law. It is a style of debate no longer restricted to results and conclusions but to assumptions, starting points and presuppositions. There is thus a permanent need for background information. Hence transparency obligations and concomitant 'information rights are not only important because they support the traditional process of democratic steering and accountability, but also because they can serve as a
tool in helping to expand the reflexive nature of democracy. ${ }^{129}$ Finally, if one believes that in post-modern democracies 'information (rather than representation by way of vote) has become one "currency of

${ }^{124}$ Grigorescu, 'Transparency of Intergovernmental Organizations' 2007 (n 7), 642.

125 Gutmann/Thompson, Democracy and Disagreement1996 (n 54), ch. 3.

126 Ibid., 95. ${ }_{127}$ Ibid., 103, with regard to 'publicity'. ${ }^{128}$ Ibid., 103.

129 Bovens, 'Information Rights' 2002 (n 52), 325. 
democracy"', ${ }^{130}$ then an increased transparency of the international legal system has specific democratic value.

International law-making is already to some extent deliberative and reflexive, and increased transparency would make a contribution here. In the interest of further democratization of the international legal process, transparency should be improved further. ${ }^{131}$ In practice this would mean that rule-making sessions in international organizations or conferences of the parties should combine public (live-streamed through the internet) and in camera sessions, with publicness as the basic rule accompanied by due exceptions for deliberation (see pp. 574-83), and for possible security, business and privacy reasons. This would include, maybe only with a time-lag, the publication of legislative drafts, too. The facilitation of technical access to the internet in disadvantaged world regions should be a high priority of UN politics in order to improve democratic inclusiveness. Transparency in itself does not bring about democracy - it is solely a precondition for democratic procedures.

\section{Transparency and Accountability}

The exercise of political power should entail accountability. ${ }^{132}$ Because not only States but other transnationally relevant actors exercise political power, these should be accountable to their principals as well. ${ }^{133}$ Transparency and access to information are necessary components of

${ }^{130}$ Devika Hovell, 'The Deliberative Deficit: Transparency, Access to Information and UN Sanctions', in Jeremy Matam Farrall/Kim Rubinstein (eds.), Sanctions, Accountability and Governance in a Globalised World (Cambridge University Press, 2009), 92-122, 97, internal references omitted.

${ }_{132}^{131}$ Peters, 'Dual Democracy' 2011(n 68), 330.

132 Accountability can be defined as 'a relationship between an actor and a forum, in which the actor has an obligation to explain and to justify his or her conduct, the forum can pose questions and pass judgment, and the act his or her conduct, the forum can Bovens. 'Analysing and Assessing European Law Journat $13(2007), 447-468,450)$. Grity. A Conceptual Framework', European Law Journal $13(2007), 447-468,450)$. Grant and Keohane define accountability as the implication that some actors have the right to hold other actors to a set of standards, to judge whether they have fulfilled their responsibilities in light of these standards, and to impose sanctions if they determine that these responsibilities have no been met (Ruth Grant/Robert Keohane, 'Accountability and Abuses of Power in World Politics', American Political Science Review 99 (2005), 29-43, 29).

${ }^{3}$ On accountability in global governance, see Anne Peters/Till Förster/Lucy Koechlin, 'Towards Non-State Actors as Effective, Legitimate and Accountable Standard Setters', in Peters et al., Non-State Actors 2009 (n 63), 492-562, 524-536. any functioning accountability scheme. ${ }^{134}$ Transparency is valuable
because it helps to alleviate (even if it can never completely rectify) the information asymmetry between 'agent' and 'principal',

Crucially, accountability requires sanctions or disempowerment mechanisms. The most common and effective political sanction, namely democratic elections, is lacking on the global plane, and global elections by a global citizenry are unfeasible. Therefore, instead of legal and formal accountability mechanisms, non-legal and informal sanctions are to the fore, notably political and financial sanctions as well as those affecting reputation. Just like democratic elections, these sanctions are either dysfunctional or utterly impossible without transparency. Against this background, it is unsurprising that the International Law Association's declared principles on the accountability of international organizations (2004) highlight transparency 'in both the decision-making process and the implementation of institutional and operational decisions' as a principle of good governance in international organizations, and thus as a principle securing their accountability. ${ }^{136}$

Another question is to whom the accountability of international law and policy-makers, notably the international organizations, should extend - to members of specific organizations, to all States, to a global citizenry? One critique is that, although those actors are accountable, they are accountable to the wrong constituencies. In this context, Allen Buchanan and Robert O. Keohane usefully distinguish between 'narrow' and 'broad' accountability. ${ }^{137}$ Broad accountability means not only allowing those who presently receive the accounts (the States, notably

134 Hetty Kovach/Caroline Nelligan/Simon Burall, 'One World Trust (2003): Power with-

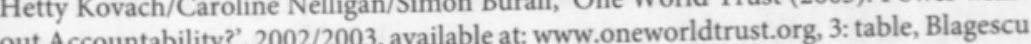
out Accountability? , 2002

135 et al., Accountability of Transnation is the principal, an information asymmetry will In a democracy, where the citizenry is the principal, an fully dialogical. This is all the always persist. Communicative structure can never be fully dialogical. This is all the more true on a global scale. (Simone Chambers, 'Behind Closed Doors: Publicity, Secrecy and the Quality of Deliberation', The Journal of Political Philosophy 12 (2004), 389-410, 410)

136 International Law Association, Report of the Seventy-first Conference (London: International Law Association, 2004), part one, section one. The principles state that '1. IOs should, as a general rule, adopt normative decisions in a public vote; 2 . Meetings of non-plenary organs should in principle be public unless inappropriate; 3. Nonplenary organs of an IO should as a general rule grant through their Rules of Procedure an appropriate status to Member States, other States, and non-State entities particularly affected by decisions to be taken or contributing to operational activities'. Ibid., 8.

137 aftected by decisions 'Ge bernance Institutions' 2006 (n 69), especially 427, with a link to transparency. 
the member States of specific organizations) but others (such as NGOs and populations) to contest the very terms of accountability. The gist is that 'broad transparency is needed for critical accountability, 138 . accountability. ${ }^{138}$ The broader constituencies should be enabled in and the capacity for revising the accountability, information requires broad transparency: institutions must facilitate positive information externalities to permit inclusive, informed contestation of their current terms of accountability. ${ }^{, 139}$ Seen in this contestation of becomes even more important for ${ }^{2}{ }^{139}$ Seen in this way, transparency the accountability mitan accountability because it can address

themselves arency also works in the other direction. The institutions themselves are aware of the fact that information about them is spread This will be sut they do not know exactly what is publicly known. criticized. ${ }^{140}$ Thincentive to avoid behaviour for which they may be criticized. ${ }^{140}$ This mechanism is also apt to increase accountability.

\section{Transparency as a Proxy}

Transparency, participation and accountability constitute the tryptichon of global good governance. The frequent mentioning of these kindred values in international political and legal texts is owing to the expectation that transparency will increase the accountability of the internation actors and enhance participation.

But is not transparency merely a surrogate, replacing the much more difficult substantive issues of democracy, good governance, economic efficiency, social justice and the rule of law ? $^{141}$ Is the quest for transparency misguided because it aims only at the symptoms and hides the causes? Is it 'a triumph of form over results'? ${ }^{142}$ Does not striving for transparency become 'a distraction, diverting time and resources from substantive outcomes'? ${ }^{143}$ Are we merely performing 'rituals of verification'? ${ }^{144}$ Have we erected an 'ideology of transparency' which

${ }^{138}$ Ibid., $428 .{ }^{139}$ Ibid., 429 .

Buchanan and Keohane have called this a 'productive uncertainty' (Buchanan/ Keohane, 'Global Governance Institutions' 2006 (n 69), 430).

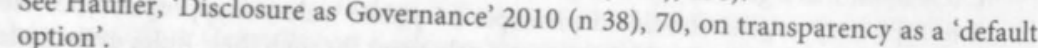

142 Option'.

143 Gee ibid., 69, on the Extractive Industries Transparency Initiative.

144 Gupta, 'Transparency under Scrutiny' 2008 (n 1), 4.

Michael Power, The Audit Society: Rituals of Verification (Oxford University Press,
1997). replaces the true democratic ideal ${ }^{145}$ With regard to the private sphere, Larry Catá Backer points out that transparency here is a substitute which 'does not seek to directly engage the foundational ideology' of shareholder welfare-maximization (as opposed to also taking into account stakeholder concerns). ${ }^{146}$ Transparency might be 'too soft to create real accountability.' ${ }^{147}$ More pernicious even, the focus on transparency might prove counterproductive by conveying a false impression of accountability, which in turn serves as a pretext for not tackling the hard problems and thus ultimately preventing political reform.

In contrast to these sceptical voices, Allen Buchanan and Robert Keohane suggest that transparency can serve as a proxy for the satisfaction of legitimacy criteria. ${ }^{148}$ The reason is that it is 'easier for outsiders to discover whether an institution is not responding to demands for information relevant for determining whether it is violating its own prescribed procedures, than to determine whether it is in fact violating them.' It is relatively easy to tell whether an international organization generates or systematically restricts access to the information that outsiders would need in order to evaluate its effectiveness. 'If an institution persistently fails to cooperate in making available to outsiders the information that would be needed to determine whether [certain legitimacy criteria] are satisfied, that by itself creates a presumption that it is illegitimate. ${ }^{, 149}$

There does exist the danger that certain types of transparency will degenerate to 'empty titles of legitimacy'. ${ }^{150}$ But the transparency discourse is ambivalent and use of the concept ranges from good faith to cynicism. More importantly, the debate on transparency not only 'masks' other issues behind it but itself reconfigures the reality of global

145 Pierre Rosanvallon, La contre-democratie: La politique à Page de la défiance (Paris: Seuil, 2006), 262: 'la perspective de la transparence se substitue dorénavant à un exercice de la responsabilité que l'on a désespéré de pouvoir organiser; elle accompagne une sorte d'abandon des objectifs proprement politiques au profit de la valorisation de qualités physiques ou morales $(. .$.$) . Une véritable idéologie de la transparence c'est$ ainsi peu à peu érigée en lieu et place de l'idéal démocratique de production d'un monde commun'.

${ }^{46}$ Larry Catá Backer, 'Transparency and Business in International Law: Governance between Norm and Technique', chapter 18 in this volume.

147 See Hale, 'Transparency, Accountability and Global Governance' 2008 (n 8), 74.

148 See Buchanan/Keohane, 'Global Governance Institutions' 2006 (n 69), 428. The authors' legitimacy criteria are minimal moral acceptability, comparative benefit and authors' legitimacy criteria are minimal moral acceptability, comparative
integrity.

149 integrity

49 Ibid., 429. ${ }^{150}$ Hölscher, Öffentlichkeit und Geheimnis 1979 (n 80), 170. 
governance. The gist is that transparency is indeed a substitute but $a$ necessary one because it replaces, in a global and pluralistic political space, the unattainable certitude and conviction about the 'right' international law and policy through a procedural device allowing everyone to form their own opinion on matters of global governance. Accompanied by mechanisms of participation, transparency helps to shape and revise those matters of global governance through public debate. ${ }^{151}$ For example, transparency in international patent law has led to the involvement of competitors and NGOs such as Greenpeace and has thereby improved the balancing of the divergent interests at stake when conferring exclusive rights, as shown by Thomas Cottier and Michelangelo Temmerman in Chapter 8 . The importance of transparency, even if only a proxy for outcomes, is demonstrated by the fact that with regard to many international events, such as environmental catastrophes or financial scandals, the lack of transparency regarding causes and governmental reactions or omissions often eclipses the perceived importance of the event itself. ${ }^{152}$ Japanese information policy in the aftermath of the nuclear catastrophe of Fukushima in 2011 is a recent example.

To conclude, while transparency policies to a certain degree generate only an ersatz legitimacy and may even at times be counterproductive, they more often seem 'a reasonable initial step ${ }^{\text {'153 }}$ towards improving the accountability and legitimacy of international law and governance.

\section{Drawbacks of Transparency}

Transparency must not be excessive. Too much transparency, the 'wrong kind' of transparency, ${ }^{154}$ transparency in the wrong moment, transparency with respect to certain contents or towards certain recipients may cause political and social problems both in terms of domestic and international law as well as regarding governance. ${ }^{155}$ The chapters of

${ }^{151}$ It is of course difficult to prove any causal relation between the procedural requirements of information disclosure and substantive improvements (for example in environmental policy). (Mol, 'The Future of Transparency' 2010 ( $\mathrm{n}$ 62), 138.)

152 Oliver, What is Transparency? 2004 (n 8), 1; Mol, 'The Future of Transparency' 2010 (n $62), 139$.

${ }_{154}^{153}$ Haufler, 'Disclosure as Governance' 2010 (n 38), 70.

Andrea Prat, 'The Wrong Kind of Transparency', American Economic Review 95 (2005), 862-877.

5 From a comprehensive international relations perspective, see Lord, Global Transparency 2006 (n 76). this book highlight some typical or possibly negative effects of too much transparency.

Analytically speaking, we can first of all distinguish between the intrinsically negative effects of transparency, notably the dangers posed to the quality of deliberations, and countervailing legitimate interests such as security, ${ }^{156}$ privacy and business or trade secrets. ${ }^{157}$ Second, as is the case with basically all policies, transparency measures have their financial costs and may be unfeasible due to time and space constraints. Third, transparency may only be simulated through data-flooding ('drowning in disclosure'), ${ }^{158}$ disinformation and propaganda, something which has traditionally played an important role in international relawhich has traditionally played an ${ }^{159}$ Orna Ben-Naftali and Roy Peled cite the example of then US Secretary of State Colin Powell's speech before the UN Security Council in February 2003 on alleged Iraqi weapons of mass destruction, which persuaded the American public of the need to go to war in Iraq, although it was gross misinformation. ${ }^{160}$ However, the remedy against information overload and disinformation seems not to be the reduction of transparency but rather increased transparency and the use of filtering systems to distinguish hokum from real information.

Transparency has been further criticized as undermining trust. It has been argued that 'excessive' transparency policies have not reduced but even fuelled public distrust, ultimately because of misinformation and

${ }^{156}$ Anne Peters, 'Transparency, Secrecy, and Security: Liaisons Dangereuses', in Julia Iliopoulos-Strangas/Oliver Diggelmann/Hartmut Bauer (eds.), Rechtsstaat, Freiheit und Sicherheit in Europa/Rule of Law, Freedom and Security in Europe/Etat de droit, liberté et sécurité en Europe, Societas Iuris Publici Europaei vol. 6 (Baden-Baden: Nomos, 2010), 183-243.

157 For example, see Agreement on Trade-related Aspects of Intellectual Property Rights, 15 April 1994, 1869 UNTS 299, art. 39. IAEA, Model Protocol Additional to the Agreement(s) between State(s) and the International Atomic Energy Agency for the Application of Safeguards, INFCIRC/540 (Corrected), September 1997, art. 15 requires the International Atomic Energy Agency to 'maintain a stringent regime to ensure the International Atomic Energy Agency to commercial, technological and industrial effective protection against disclosure of commercial, tochno its knowledge'.

158 Gecrets and other confidential information comansparency under Scrutiny' 2008 (n 1), 4.

159 Gupta, 'Transparency under Scrutiny' 2008 (n 1), 4. EU: '[t]he impression of trans-

Holzner and Holzner quote a senior official of the EU: ' $t]$ he impression of transparency is that it is a straight ray of light. But it can be simulated by a thousand mirrors. (Burkart Holzner/Leslie Holzner, Transparency in Global Change: The Vanguard of Open Society (University of Pittsburgh Press, 2006), 102).

160 Orna Ben-Naftali/Roy Peled, 'How Much Secrecy Does Warfare Need?', chapter 13 in this volume. 
information overflow. ${ }^{161}$ This view seems one-sided because intransparency is also apt to generate distrust. Secrecy is often understood to indicate bad intentions, and disclosure is perceived as a sign of trustworthiness. ${ }^{162}$ Moreover, in judging whether to place our trust in a certain entity or to deny it our trust, we must first have sufficient information. With regard to international relations, liberals such as the German Karl Heinrich Ludwig Pölitz realized this as early as the nineteenth century: 'Sollen Völker unter rechtlichen Verhältnissen neben einander bestehen, und die wechselseitigen Verbindungen des Handels und des übrigen Verkehrs durch ihr gegenseitiges Zutrauen begründet, erleichtert und gesichert werden; so muß jedes Volk wissen, wie es mit dem andern daran ist. Dies kann nur durch gegenseitige Oeffentlichkeit bewirkt werden. ${ }^{, 163}$ In contemporary international law with respect to disarmament, one of the 'essential functions' of verification is 'to prevent any risk of cheating and to build confidence' - as Mirko Sossai points out. ${ }^{164}$ So, while greater transparency as such is no guarantee that fewer misunderstandings will take place and increased trust will ensue, transparency is more often than not perceived to build trust rather than to undermine it.

${ }^{161}$ Ono

Onora O'Neill, A Question of Trust, The BBC Reith Lectures 2002 (Cambridge University Press, 2002), see especially 70: '[i]f we want to restore trust we need to reduce deception and lies rather than secrecy. Some sorts of secrecy indeed support deception, others do not. Transparency and openness may not be the unconditional goods that they are fashionably supposed to be. By the same token, secrecy and lack of

162 transparency may not be the enemies of trust'.

Florini, 'Conclusions' 2007 (n 77), 339. On trust-building through transparency, see Jutta Brunnée/Ellen Hey, 'Transparency and Intorion transparency, see Institutions', chapter 2 in this volume. In chapter 11 in this volume, Emily Bronmental and Allyn Taylor recall that with respect to the intranspolume, Emily Bruemmer committee, WHO found that "Iallthough confidentiation able effort to protect the members from suspicions that the the members from external pressures, this paradoxically fed suspicions that the organization had something to hide' (WHO, Sixty-fourth World Report of the Review Conentation of the International Health Regulations (2005): Report of the Review Committee on the Functioning of the International Health Regulations (2005) in Relation to Pandemic (H1N1) (2009), Report by the Director${ }_{63}$ 'General, A64/10, 5 May 2011, 16).

Should nations coexist in legal relations, and the mutual links of commerce and the other traffic be founded, facilitated, and secured through their mutual trust; then every people must know how it stands with the other. This can only be achieved by mutua publicity.' Karl H. L. Pölitz, Die Staatswissenschaften im Lichte unserer Zeit, vol. Leipzig 1847, 133 (emphasis added; trans, by this author). See also Hölscher,

Offentlichkeit und Geheimnis 1979 (n 80), 169.

Mirko Sossai, 'Transparency as a Cornerstone of Disarmament and Non-proliferation Regimes', chapter 15 in this volume.
An important point is that transparency measures can be circumvented: the legal and political actors might hold conclave behind the façade of the public meeting, keep secret files apart from those that are public, or minimize record-keeping altogether. If such are the foreseeable or inevitable consequences of transparency or too much transparency in a certain context, in the end the entire policy will be rendered ineffective or even counterproductive and thus create yet more intransparency. For example, Luis Miguel Hinojosa Martínez predicts venue-shifting for those sensitive negotiations on the regulation of financial markets, spending cuts, or budgetary priorities if they were to be conducted under constant public scrutiny. He concludes that excessive disclosure would likely transfer those negotiations to less formal and more opaque forums and would seriously hamper the role of international financial institutions as trusted advisors.' ${ }^{165}$ The likelihood of such effects must be gauged by the designers of such institutions.

In the international as in the domestic realm, some types of transparency may also engender nothing more than a 'politics of spectacle ${ }^{166}$ in which neither the decision-makers nor the public truly engage. In international investment arbitration, Julie Maupin gives a mixed assessment of the danger of politicization. As for the 'worry that transparent proceedings might "re-politicize" investor-state disputes', she regards it as 'misplaced'; but purely contract-based claims may introduce different considerations. ${ }^{167}$ Extensive transparency about legal and political processes can bring about an 'ersatz public reason', a 'plebiscitary reason', which is shallow or appeals to the worst human instincts. ${ }^{168}$ But from a realistic standpoint, modern democracy will always to some degree produce these effects.

To conclude, transparency can be beneficial and pernicious, and the overall effects depend on what is revealed, when it is revealed, and to whom. As a governance mechanism, transparency is a double-edged sword.

165 Luis Miguel Hinojosa Martínez, 'Transparency in International Financial Institutions', chapter 4 in this volume.

166 Roberts, Government Secrecy 2006 (n 48), 236

167 Julie Maupin, 'Transparency in International Investment Law: The Good, the Bad and the Murky', chapter 6 in this volume.

168 Chambers, 'Behind Closed Doors' 2004 (n 135), 389, 393 and 398. 
15. Transparency and Deliberation: Which Exceptions Are Needed and When?

A core question is to what extent transparency undermines the quality of deliberations, because deliberation is at the centre of all types of international decision-making and setting up of rules, in conferences of the parties, in compliance monitoring bodies, or in international courts and tribunals, and notably in diplomatic negotiations.

\subsection{Transparency and Diplomacy}

A related aspect is the traditional ethos of confidentiality in diplomacy. A British diplomat wrote: 'the old principle that the art of negotiation depends on reliability and confidence is an eternal principle. ${ }^{169}$ An aggravating factor was that, historically, diplomacy had been an aristocratic affair and to that extent profoundly anti-democratic: in the days of the old diplomacy it would have been regarded as an unthinkable vulgarity to appeal to the common people upon any issue of international policy. ${ }^{, 170}$

The more the processes of international law move away from the diplomatic mode, the more they lend themselves to publicity. This not only applies to law-making but also to the settlement of disputes. In the 1950 s it was still worth pointing out: '[D]ans son origine la justice internationale s'affirme par une différenciation des procédés diplomatiques, notamment dans la mesure où les commissions mixtes diplomatiques se transforment progressivement en commissions arbitrales. Il est donc naturel qu'elle évolue également vers des formes et des procédures de plus en plus ouvertes à la publicité, ainsi que le prouvent notamment les statuts des Cours internationales proprement dites. ${ }^{, 171}$

Moreover, even in the realm of diplomacy, opaqueness has probably never been an absolute value. By the late nineteenth century, governments realized that they could achieve foreign policy objectives only with the support of the domestic public. They therefore attempted to pursue a dual strategy: secrecy towards the foreign States, but openness towards their people. The German Chancellor Otto von Bismarck understood this trade-off but did not say how it was to be attained: '[I]nwieweit nun die Geheimhaltung, die diskrete Schonung des internationalen

${ }_{170}^{169}$ Harold Nicolson, Diplomacy (Oxford University Press, 3rd edn, 1963), 255.

${ }^{170}$ Ibid., $168 .{ }^{171}$ Reuter, 'Droit au secret' 1956 (n 73), 64.
Vertrauens, dem Bedürfnisse, die Öffentlichkeit rechtzeitig aufzuklären über den politischen Gang der Regierung, geopfert werden darf, ist eine schwer zu entscheidende Frage. ${ }^{172}$ An extension of this is the newer strategy of 'public diplomacy', which includes the endeavour to persuade the foreign public.

A recent example of a commitment to transparent diplomacy is the climate negotiations. The conference/meeting of the parties of the UNFCCC and Kyoto Protocol (COP 16/CMP 6), held in Cancun in 2010, was explicitly conducted under the heading of transparency. This was in line with the pertinent UNFCCC guidelines ${ }^{173}$ but was also specifically highlighted by the hosts: the Mexican conference president gave 'full commitment to the principles of transparency and inclusiveness. There will be no parallel or overlapping discussions and I will continue ensuring that all positions are taken into account. ${ }^{, 174}$ What is at stake when making (diplomatic) deliberations transparent?

\subsection{Negative Effects of Transparency}

Hans Morgenthau warned against 'the vice of publicity' in diplomatic negotiations: '[i]t takes only common sense derived from daily experience to realize that it is impossible to negotiate in public on anything in

172 To what extent secrecy, the discrete consideration for international trust, may be sacrificed for the desire to inform the public timely about the political course of government, is a question that is difficult to decide.' Speech in the 24th session of the Reichstag of the Norddeutscher Bund, 22 April 1869, in Otto von Bismarck, Werke in Auswahl, vol. 4 (Stuttgart: Kohlhammer, 1968), 334-337, 336; see also Hölscher, Offentlichkeit und Geheimnis, 1979 (n 80), 168.

173 The guidelines for the participation of representatives of non-governmental organizations at meetings of Che participation of observers to the process promotes transparency in this increasingly participation of observers to

complex universal problem'.
174 UNFCCC, Informal Stocktaking Plenary: Statement by Her Excellency, Mrs Patricia 4 UNFCCC, Informal Stocktaking Plenary: Statement by Her Excellency, Mrs Patricia
Espinosa, COP 16/CMP 6 President, 8 December 2010. In the same sense, see the Espinosa, COP 16/CMP 6 President, 8 December 2010. In the same sense, see the
informal meeting of the president, statement of 5 December 2010: ' $[T]$ he Mexican Presidency will continue to work with full transparency and according to established United Nations procedures'. See also UNFCCC, Subsidiary Body for Implementation, Synthesis Report on Ways to Enhance the Engagement of Observer Organizations, FCCC/SBI/2010/16, 19 October 2010, with a view to the 33rd session in Cancun, 30 FCCC/SB/2013 ability and information-sharing' (paras. 16-17 and 26-28). 
which parties other than the negotiators are interested. ${ }^{175}$ In a judgment relating to the Watergate scandal, the US Supreme Court stated: '[h] uman experience teaches that those who expect public dissemination of their remarks may well temper candour with a concern for appearances and for their own interests to the detriment of the decision-making process.' 176

Therefore, in order to mitigate the negative effects of transparency on deliberations, transparency laws and policies will typically contain 'deliberative exceptions'. For example, in the EU, access to an institutional document 'which relates to a matter where the decision has not been taken by the institution, shall be refused if disclosure of the document would seriously undermine the institution's decision-making process, unless there is an overriding public interest in disclosure. ${ }^{, 177}$ Luis Miguel Hinojosa Martínez quotes the World Bank's justification for secret deliberations: if the view of each ED [Executive Director] is immediately known to the public, it may put undue pressure on EDs, and could also politicize the Bank's decision-making process' - and above all for those executive directors who represent several constituencies. ${ }^{178}$

Are deliberation exceptions justified? What exactly are the inhibiting effects of allowing non-participants to listen to deliberations? Sissela Bok has described these as follows: ${ }^{179}$ when deliberating before an audience, the deliberants tend to become more inflexible, more radical, and/or they lose candour, becoming averse to risky or innovative opinions.

${ }^{175}$ Morgenthau continued: '[T]his impossibility derives from the very nature of negotiation and from the social context in which negotiations generally operate (...). This degeneration of diplomatic intercourse into a propaganda match is, then, the inevitable concomitant of the publicity of the new diplomacy'. Hans Morgenthau, Politics among Nations (New York: Alfred A. Knopf, 1950), 431-433.

${ }_{176}$ US Supreme Court, US v. Nixon, 418 US 683 (1974), 705.

177 EU Transparency Regulation, 2001 (n 61), art. 4(3). Under the IMF Transparency Decision of 17 March 2010, the Executive Board of the IMF will not allow publication when it may undermine 'the Fund's decision-making process'. On 'deliberative information', also see WB, 'World Bank Policy on Access to Information', 2010 (n 94), section 16 (see Luis Miguel Hinojosa Martínez, 'Transparency in International Financial Institutions', chapter 4 in this volume). In the WTO dispute settlement, panel and Appellate Body deliberations are confidential (DSU, 1994 (n 53), art. 14(1) and 17 (10)). On the related working procedures and case law, see Panagiotis Delimatsis, 'Institutional Transparency in the WTO', chapter 5 in this volume.

${ }^{178}$ See WB, Operations, Policy and Country Services, 'Toward Greater Transparency through Access to Information: The Bank Disclosure Policy', 16 October 2009, accessible via: http:// siteresources.worldbank.org, annex B, para. 11. Luis Miguel Hinojosa Martínez, 'Transparency in International Financial Institutions', chapter 4 in this volume.

179 Bok, Secrets 1982 (n 74), 175 and 184.
Transparency tempts the participants to rigidity and to posturing, increasing the chances of a stalemate in which no compromise is possible, or alternatively, of a short-circuited and hasty agreement. To pull back from a bargaining position, often done solely for strategic purposes, might be interpreted, if done in full view of the public, as giving in to an opponent. The public gaze tempts deliberators to bypass creative or stilltentative ideas and leads to premature closure. In sum, the chances for collective learning are diminished.

Concomitantly, the beneficial effect of excluding the public from deliberations is that this allows for fuller consideration of the matter at hand. Deliberators dare to express controversial views behind closed doors, but they also feel as if they have greater freedom to change their minds. They can engage in a tentative process of learning and of assimilating information, considering alternatives and weighing consequences all of which is needed to arrive at a coherent position. In sum, deliberation behind closed doors can proceed through a process of trial and error, through proposal and counterproposal, through persuasion and bargaining, and sometimes through threat. This is impossible with pressure from the public, including that exerted by special interest groups. ${ }^{180}$

The judicial deliberation and drafting of decisions is usually shielded from scrutiny in the sphere of international adjudication, and the rules of various international courts show 'a considerable degree of uniformity' in this respect. ${ }^{181}$ Neumann and Simma mention a number of reasons why the secrecy of deliberations in international adjudication is even more important than in the domestic realm - notably to prevent governments from controlling judges. ${ }^{182}$

In international law-making (treaty negotiations), an aggravating factor of transparency is that the inflexibility and posturing of participants as well as the public pressure of domestic constituencies or special interest groups may frequently lead to a complete breakdown of negotiations so that no desirable outcome results. In fact, these were the reasons given by the representatives of the Great Powers at the opening of the 1919 Paris Peace Conference: '[O]pen proceedings would lead to premature public controversy, not only within the interested States, but

${ }^{180}$ Ibid.

181 Thore Neumann/Bruno Simma, 'Transparency in International Adjudication', chapter 17 in this volume.

182 Ibid. 
between the interested nations, render infinitely more difficult the process of give and take, so essential to the negotiations, and hinder the unanimity of agreement which is vital to success'. ${ }^{183}$

\subsection{Positive Effects of Transparency}

The intransparency of the Paris Peace Conference was all the more conspicuous as it was only shortly before that American President Woodrow Wilson had stated in his Fourteen Points - 'the only programme of the world's peace' - that there should be '[o]pen covenants of peace, openly arrived at, after which there shall be no private international understandings of any kind, but diplomacy shall proceed always frankly and in the public view. ${ }^{184}$ This ideal programme for transparency (one that was not to be realized) had been motivated by a concern for international peace and security. At the beginning of the twentieth century the European practice of secret diplomacy had contributed to an atmosphere of mutual distrust among nations which in hindsight was seen as a catalyst for the outbreak of World War I. Gaining ground by the end of the war was the idea that democracy and the power of public opinion would be an effective means of preventing war. ${ }^{185}$ The expectation was that transparency (public scrutiny) would restrain States from concluding treaties which would risk public disapproval, thus making it more difficult to cloak activities antithetical to world peace and security under the mantle of the law. ${ }^{186}$

Another beneficial effect of a public audience for deliberations is what Jon Elster has called the 'civilizing force of hypocrisy'. ${ }^{187}$ Publicity (transparency) might force law-makers and decision-makers to explain

${ }^{183}$ Geo Finch, 'The Peace Conference of Paris 1919', American Journal of International Law 13 (1919), 159-186, 167. It was based upon this reasoning that the conference adopted the rule that the press should be admitted to plenary sessions but not to commissions and committees. In addition, 'upon necessary occasions', the deliberations of the plenary could be closed as well.

tions of the plenary could be closed as well.
184 President Wilson in a joint session of the US Congress on 8 January 1918.

${ }^{185}$ Karl Willhelm Geck, 'Die Registrierung und Veröffentlichung völkerrechtlicher Verträge', Zeitschrift für ausländisches öffentliches Recht und Völkerrecht 22 (1962), $113-211,122-23$.

${ }^{186}$ Karl Zemanek, 'Geheimverträge', in Karl Strupp/Hans-Jürgen Schlochauer (eds.), Wörterbuch des Völkerrechts, vol. 1 (Berlin: Walter de Gruyter, 1960), 633-635, 634.

187 Jon Elster, 'Deliberation and Constitution-Making', in Jon Elster (ed.), Deliberative Democracy (Cambridge University Press, 1998), 97-122, 111. On the empirical testing of that hypothesis, see the text below together with nn 196-199. their positions with reference to socially acknowledged norms. Social pressure will cause them to base their statements on claims of general interest rather than on selfish appeals. Even if hypocritical, these statements may still generate better outcomes because the 'bad' arguments are officially banned and therefore have much less power to influence the decision that is ultimately reached. ${ }^{188}$

With regard to international treaty-making, an important aspect is its two-level setting. Here, too, transparent treaty negotiations may indeed fail to produce a treaty text due to the inhibiting effects stated above. However, while secret negotiations might lead to a treaty text, this treaty must eventually be published; if it then fails to gain the support of the domestic public, it will not be ratified. Transparency must be carefully timed and parcelled so as to avoid this catch-22 situation.

\subsection{Determining the Proper Mix}

The 'deliberation exception' is the most intriguing challenge to the quest for transparency because here the proponents of intransparency claim to further precisely those objectives which the principal rule of transparency also seeks to promote, namely enabling and improving deliberation and better decision-making. ${ }^{189}$ Unfettered transparency would work against the rule's rationale. This implies that absolute transparency is not to be recommended.

So the problem for institutional designers is to properly mix the transparent and intransparent elements of deliberations and to adequately circumscribe the zones and phases of intransparency. When creating closed spaces for deliberation it should first be kept in mind that the deliberators themselves tend to exaggerate the need for intransparency. Second, the issue is to some extent historically contingent. In early parliamentarianism,

${ }^{188}$ Jon Elster focused notonly on public-versus-private communicative action but contrasted the communicative modes of 'arguing' (reason-giving) and 'bargaining' (threats and promises). He thought that 'secrecy tends to induce bargaining and publicity to induce argument' (Jon Elster, 'Strategic Uses of Argument', in Kenneth J. Arrow et al. (eds.), Barriers to Conflict Resolution (New York: Norton, 1995), 237-257, 252). 'Roughly speaking, arguing is better than bargaining because of the civilizing force of hypocrisy, and private settings are better than public settings because they lave less room for precol anter than public settings because they leave less room for pre-commitment strategies and overbidding $(. .$.$) . The real choice, therefore, may be between the second-best and the third-best$ options' (ibid., 250). (Original in Jon Elster, Arguing and Bargaining in Two Constituent Assemblies, The Storrs Lectures (New Haven: Yale Law School, 1991).

189 For a good exposition of the problem, see Gutmann/Thompson, Democracy and Disagreement 1996 (n 54), 114-126. 
deliberative secrecy was reclaimed for processes for which we nowadays deem transparency clearly appropriate, such as parliamentary debates and constitution-making. ${ }^{190}$ For example, the American Constitutional Convention of 1787 deliberated behind closed doors and only presented its work to the public when it had a finished product. James Madison, who defended secret deliberations in this case, later wrote that 'no Constitution would ever have been adopted by the convention if the debates had been public. ${ }^{191}$ Today, in an era in which constitution-making is closely monitored and steered by international institutions and thus to a large extent 'internationalized', such intransparency is inconceivable. For example, the European Constitutional Convention of 2004 was not only a public affair but actively sought input from the European citizenry. This could however not prevent the Constitutional Treaty's ratification failing so that the Treaty never entered into force.

\subsection{Empirical Findings}

Finally and most importantly, the granting of 'deliberation exceptions' and their extension and timing should be based on systematic research into this matter. The beneficial and obnoxious effects of transparency/ publicity on communicative action have been theoretically modelled and empirically tested with regard to numerous deliberations (constitutionmaking, treaty-making, decision-making in the EU Council of Ministers, ${ }^{192}$ and the like). ${ }^{193}$ The classic historical study is Jon Elster's

${ }^{190}$ In early parliamentarianism (which began in England in the seventeenth century), there was a debate over whether parliamentary debates should be public or closed. The common expectation was that deliberations would be hampered by publicity. Secrec was only gradually abandoned. See David Stasavage, 'Open-Door or Closed-Doo Transparency in Domestic and International Bargaining', International Organization 58 (2004), 667-704, and specifically 688 for further references.

191 Max Farrand (ed.), The Records of the Federal Convention of 1787, vol. 3 (New Haven: Yale University Press, 1911), CCLXVII: Jared Sparks: Journal.

192 David Stasavage, 'Does Transparency Make a Difference? The Example of the European Council of Ministers', in Christopher Hood/David Heald (eds.), Transparency: The Key to Better Governance, Proceedings of the British Academy 135 (Oxford University Press, 2006), 165-179. He finds that the closed-door setting of Council decisionmaking has facilitated attempts to strike bargains, for there has been a greater propensity for 'real' deliberation in most secretive settings (such as COREPER and the economic and financial committee).

193 See notably Stancial 'COpen-Door or Closed-Door?' 2004 (n 190), 667-704, for (n) bargaining. Ellen E. Meade and David Stasavage developed a theoretical model of comparison of the public deliberations of the Assemblée constituante in France of 1789 and the secret deliberations of the American Constitutional Convention in Philadelphia in 1787. Elster found that the non-public American constitutional debate was of a high quality, remarkably free of cant, and grounded in rational argument. In contrast, the public debates of the Assemblée were heavily tainted with rhetoric demagoguery and overbidding. ${ }^{194}$ With regard to international treatymaking, Barbara Koremenos has sought to demonstrate that transparency may often lengthen the bargaining process and give interest groups too much influence on the treaty's design, which might then lead to the treaty's rejection by powerful States and even make it impossible to achieve outcomes with net social benefits. ${ }^{195}$

Jon Elster's aforementioned hypothesis on the 'civilizing' force of transparency has been empirically tested in the project 'Arguing and Bargaining in Multilateral Negotiations'. ${ }^{196}$ That project examined conferences within numerous international treaty regimes (the Nuclear Non-proliferation Treaty, the Ottawa Treaty Banning Landmines, the Statute of the International Criminal Court (ICC), the Child Labour Convention, and EU negotiations on greenhouse gas emissions). The result of these case studies was that much depends on the subject matter

deliberation on a three-member committee and tested it using an original dataset on deliberations in the US Federal Reserve Open Market Committee. In 1993 that committee had decided to release transcripts of meetings after a delay of five years. One of mittee had decided to release transcripts of meetings afs likely to switch their position the results was that committee non after 199, i.e. when they knew that their state published (Ellen E. Meade/David Stasavage, 'Publicity or Debate and the Incentive to Dissent: Evidence from the US Federal Reserve, The Economic Journal 118 (2008), 695-717). See also James Fearon, 'Domestic Political Audiences and the Escalation of International Disputes', American Political Science Review 88 (1994), 577-592. See also Motty Perry/Larry Samuelson, 'Open versus Closed-door Negotiations', Journal of Economics 25 (1994), 348-359, which examines the phenomenon with no reference to international negotiations; Tim Groseclose/Nolan McCarty, 'The Politics of Blame: Bargaining Before an Audience', American Journal of Political Science 45 (2001), 100-119; John Fingleton/Michael Raith, 'Career Concerns of Bargainers', The Journal of Law, Economics, and Organization 21 (2005), 179-203; Prat, 'Wrong Kind of Transparency' 2005 (n 154).

194 Elster, 'Strategic Uses of Argument' 1995 (n 188), especially 251.

195 See Brot The Bar 5 (fortcoming), 'Open Covenants Theory 5 (forthcoming), giving as one example the negotiations on the Statute of the International Criminal Court

${ }^{6}$ Overview and summary of findings in Cornelia Ulbert/Thomas Risse, 'Deliberately Changing the Discourse: What Does Make Arguing Effective?', Acta Politica 40 (2005), $351-367$ 
and the institutional context of negotiations. For example, with regard to the ICC and child labour, meetings that took place under public scrutiny proved to be quite effective. Negotiators became aware of their 'social responsibility.' ${ }^{197}$ In contrast, non-transparent negotiations work better in 'mixed-motive games' (when actors have fixed preferences but would also prefer cooperation), for example in European Council summits.

Cornelia Ulbert and Thomas Risse conclude that the 'public sphere' does have the postulated 'civilising' influence on the quality of the debate if two conditions are met: first, the negotiators must be dependent on the subsequent consent or at least approval of their audiences and/or constituencies, for example at the domestic level (as in a 'two-level arguing process'), or in a transnational public sphere in which negotiators feel the need to justify and legitimize their positions. Second, the members of the audience must be assumed to be neutral at the outset of the process (more like a court), which also means that their preferences are unknown to the negotiators. ${ }^{198}$

As for the second condition, Thomas Risse hypothesized that once negotiators are certain as to the preferences of the audience whose consent they require, social norms lose their constraining effect because the negotiators need not argue but can simply employ rhetorical devices to impress their audience. If preferences of the principals are known, then 'secrecy and negotiating behind closed doors might be the only way towards problem-solving, since it enables speakers to argue "out of the box" and to work toward a reasoned consensus without having to fear that some principal in the audience might accuse her of "betraying the national interest." 199 This proposition was tested on deliberations concerning one item in the EU Treaty revision conference in Amsterdam from 1996 to 1997 (treating the issue of the EU's single legal personality), but it yielded no clear empirical result.

To conclude, depending on the setting and on certain conditions, transparency can have detrimental but also beneficial effects on the quality of international deliberations. Deliberations that are partly open and partly in camera should attempt to exploit the benefits and mitigate the drawbacks of intransparency. For example, any allowance to deliberate behind closed doors might be linked to reproducing the pluralism of the public in private by admitting certain

${ }^{197}$ Ibid., 358-359. ${ }^{198}$ Ibid., 359.

199 Thomas Risse/Mareike Kleine, 'Deliberation in Negotiations', Journal of European Public Policy 17 (2010), 708-726, 713 stakeholders. ${ }^{200}$ Another idea is to allow participants to conduct predecisional discussions and deliberations in private so long as the members of the body then publicly cite the reasons for their individual decisions and votes. ${ }^{201}$ Transparency in deliberations always implies a trade-off.

\section{The Normative Quality of Transparency}

This book's chapters have demonstrated that the (relative) transparency of international processes, mechanisms and institutions, and of the substance of international legal texts, is not just a matter of fact but a social value and yardstick for the way international organizations, regimes and even transnational business actors ${ }^{202}$ ought to behave. The question is whether that political (or moral) standard of transparency has crystallized into an international legal norm. Are there specific hard or soft legal rules, or is there an overarching international legal prescription for transparency? Within the traditional framework of sources of international law, a legal obligation of transparency can exist only as a treaty-based norm, a customary rule or as a general principle of law.

The chapters of this book have adduced a large number of international treaties which prescribe transparency in different relationships and on different issues. A well-known transparency rule applicable in inter-State relations underpins the multiple treaty-based obligations to exchange scientific or technical environment-related information among States. ${ }^{203}$ In the field of international adjudication, Thore Neumann and Bruno Simma have identified a 'considerable acquis of hard-law obligations' and a 'normative skeleton of an overarching judicial transparency principle. ${ }^{204}$ With regard to the Security Council, Antonios Tzanakopoulos (chapter 14) has argued that the Council's obligation to

200 Chambers, 'Behind Closed Doors' 2004 (n 135), 390.

201 Nicholas Johnson, 'Open Meetings and Closed Minds: Another Road to the Mountaintop', Drake Law Review 53 (2004), 11-53, 53, concerning US law with respect to agency meetings. Giving reasons provides the meta-transparency discussed below in section 18.3 .

202 On the 'outlines of a social-norm standard for transparency' of business actors, see Larry Catá Backer, 'Transparency and Business in International Law: Governance Larry Cata Backer, 'Transparency and Business in lnterna

203 between Norm and Technique', chapter 18 in this volume.
See Jutta Brunnée/Ellen Hey, 'Transparency and International Environmental See Jutta Brunnée/Ellen Hey, 'Transp
Institutions', chapter 2 in this volume.

204 Thore Neumann/Bruno Simma, 'Transparency in International Adjudication', chapter 17 in this volume. 
be transparent towards the UN member States is an 'ancillary obligation, which is imposed by the decentralized nature of the system (...). [I]f States have the right to control legality of Council action, then they must also have the concomitant (ancillary) right to demand sufficient information on which to reach a conclusion.' With regard to international investment law, in Chapter 6 Julie Maupin finds that the existence of 'an overarching norm on transparency remains to be determined.'

In any case, there is no general transparency treaty in the manner of a domestic freedom of information law. Such a treaty would not make much sense anyway because the potential obligees, recipients and objects of transparency are much too complex in the international sphere to be summarily regulated.

The obligation of transparency as customary law would require a general practice of transparency accompanied by an opinio iuris. This book has demonstrated that abundant transparency practices exist and that they are expanding. The test question for determining whether this practice is conceived as legally mandated is to entertain whether a rollback is conceivable; if not, then an opinio iuris might be deemed to exist. According to this test, there would seem to be a relevant opinio iuris.

Finally, it can be asked whether transparency is 'a general principle of law' in the sense of article 38(1) lit. c) ICJ-Statute. ${ }^{205}$ Such a general principle can be said to exist only if two conditions are met. First, it must be recognized in the municipal laws of States; and second, it must be transposable at the international level. ${ }^{, 206}$ Given the recent proliferation of transparency laws all over the world, ${ }^{207}$ the first condition would seem to have been satisfied. ${ }^{208}$ It is not necessary for every single State of the

${ }^{205}$ For a good analysis with regard to the Security Council, see Hovell, 'Deliberative Deficit' 2009 (n 130).

206 See Alain Pellet, 'Art. 38', in Andreas Zimmermann et al (eds), The Statute of the International Court of Justice: A Commentary (Oxford University Press, 2nd edn, 2012), MN 250-269, especially MN 254

${ }_{208}^{207}$ See the references in $\mathrm{n} 12$

${ }^{8}$ Hovell is more cautious, concluding that it is probably too early to refer to a general principle of international law recognizing a right of access to information. Many of the relevant enactments are too recent in origin to be able to reflect principles that can be said to be integral to any legal system, if certain of those enactments can even be said to have achieved the status of law at all.' However, she finds that 'the contemporary trends in legal systems across the globe are striking, and there are clear indications of the gradual evolution of a general principle of international hur recognizing a ight access to information' (Hovell, 'Deliberative Deficit' 2009 (n 130), 112-113). world to have enacted a formal freedom of information law, especially because the current trend will obviously continue. The more difficult point is that of transparency's transposability, bearing in mind 'that conditions in the international field are sometimes very different from what they are in the domestic, and that rules which these latter conditions fully justify may be less capable of vindication if strictly applied when transposed onto the international level. ${ }^{, 209}$ Currently, structural and substantial elements which relate to the operation of a rule of transparency are still quite different at both levels of law (see in detail above section 4). So the condition of transposability has not (yet) been fully met.

Additionally, a problem of broadness and vagueness arises. The blurry features of the concept of transparency are apt to undermine its normative power as a legally binding rule. With regard to the principle of good governance, of which transparency forms a part, it has been observed that in order to be 'legalizable' a concept 'must meet two fundamental structural preconditions: it must be sufficiently precise to generate an obligation and to assess its implementation, and it must have an obligor and an obligee. Only if these questions are answered in the affirmative, does it make sense to examine the binding force of the concept.' Transparency as such might indeed fail that test: '[1]'opacité de la transparence est de l'ordre d'illusion; elle pourrait être source de désillusions, de déceptions. Un droit qui promet trop, qui promet mal, est voué à perdre son autorité, son âme peut-être. ${ }^{211}$ This means that its vagueness as such might render the concept of transparency unsuited to function as a legal concept, as a binding rule.

As a result, it would seem difficult to argue that transparency is a norm of hard international law - and maybe it can never become one. ${ }^{212}$ But this finding might be of little relevance. Maybe the classic boxes, the

${ }^{209}$ ICJ, Barcelona Traction, Light and Power Company, Limited (Belgium v. Spain) (New Application: 1962), Separate Opinion of Judge Sir Gerald Fitzmaurice, Judgment of 5 February 1970, IC) Reports 1970, 64, 66 (para. 5). See also Pellet, 'Art. 38 ' 2012 (n 206), MN 267.

210 Beate Rudolf, 'Is "Good Governance" a Norm of International Law?', in Pierre-Marie Dupuy et al. (eds.), Völkerrecht als Wertordnung, Festschrift für Christian Tomuschat (Kehl: Engel, 2006), 1007-1028, 1026.

211 Christian Atias, 'La transparence: Exigence politique ou principe de droit', Revue générale nucléaire 29 (2003), 58-61, 61.

212 See Jonas Ebbesson, 'Global or European Only?: International Law on Transparency in Environmental Matters for Members of the Public', chapter 3 in this volume, who sees merely 'normative fragments' which give 'only limited support for international law on 
'sources' in terms of article 38 ICJ-Statute, do not tell us much about the state of international law and its power to influence the behaviour of internationally relevant actors. As Andrea Bianchi has explained, a normative transparency 'principle' (in the sense of a 'connector between the law and changing social realities') can be discerned ${ }^{213}$ whatever its doctrinal quality. And maybe as importantly, normative expectations are growing.

\section{A Human Right to Information as a Companion} of Transparency

Within States, transparency (rules on open government) has been mainly sought as a question of 'social hygiene' in order to achieve greater democratic control and social accountability of governance. Certain authors have also espoused a rights-based perspective in which 'information rights are most of all an element of citizenship'. ${ }^{214}$ The debate on international transparency is bifurcated in a similar but not identical way. It derives from both a 'managerial' and a 'rights-based' tradition, as Megan Donaldson and Benedict Kingsbury point out in chapter 19. In the managerial tradition, transparency is primarily intended to serve the efficacy of governance by using information flows in all directions. From the rights-based perspective, transparency is rather regarded as a tool for protecting the political, social and economic rights of citizens affected by global governance. ${ }^{215}$ In chapter 9 , this perspective is advocated by Jonathan Klaaren, who analyses to what extent a potential human right to information might serve as a 'vehicle' for transparency. Such a human right would have as a corollary the duty to disclose.

transparency vis-à-vis members of the public'. Alan Boyle and Kasey McCall-Smith find 'remarkably little identifiable international law underpinning this rather significant' transparency practice of international organizations and treaty bodies (chapter 16 in this volume).

213 Andrea Bianchi, 'Introduction: On Power and Illusion. The Concept of Transparency in International Law', chapter 1 in this volume, section 3, in referring to Andreas Lowe's idea of 'interstitial norms'.

214 Bovens, 'Information Rights' 2002 (n 52), 327.

215 Rovens, Gorents explanatory report, commentary on the preamble: '[T]ransparency of public authorities
(T) $(\ldots)$ is also essential to (...) the exercise of fundamental human rights'.

\subsection{A Positive Right to Governmental Information}

A right to information is enshrined in many domestic constitutional orders. ${ }^{216}$ However, this right has been traditionally interpreted as only part of the status negativus. In that reading, the right only prohibits the government from withholding 'generally accessible' information (notably information held by entities other than the State). Thus interpreted, freedom of information does not confer on individuals a positive right to obtain information held by the government. In that construction, the human right to information cannot function as a legal basis for claims to access administrative files, court proceedings or records, and it cannot function as a catalyst for the creation of governmental transparency.

The international and regional human rights covenants also grant freedom of information. ${ }^{217}$ According to their wording, everyone shall have the right to 'receive' (or to 'seek and receive') information - but these provisions do not say who the holder of that information is (private actors, the State, or even intergovernmental organizations?). In earlier individual communications, the United Nations Human Rights Committee ${ }^{218}$ and the institutions monitoring the ECHR ${ }^{219}$ had initially interpreted the right to information in the aforementioned 'liberal' and limited sense.

${ }^{216}$ For example, in the case of Germany, Basic Law, art. 5(1); for Switzerland, Federal Constitution, art. 16. The United States First Amendment to the Constitution encompasses the right to access information and ideas (US Supreme Court, Richmond Newspapers $v$. Virginia, Decision of 2 July 1980, 448 US 555 (1980)). See for an overview of the constitutional status of freed of information Roy Peled/Yoram Rabin, "The of the constitutional status of freedom of information Roy Peled/Yoram Rabin, 'The Constitutional Right to Information', Columbia Human Rights Law Review 42 (2011), 217 357-401.

217 UNGA, Universal Declaration of Human Rights, A/RES/217(III)A, 10 December 1948 art. 19; UNGA, International Covenant on Civil and Political Rights, A/RES/2200 (XXI), 16 December 1966 (ICCPR), art. 19(2); European Convention for the Protection of Human Rights and Fundamental Freedoms, 4 November 1950, 213 UNTS 221, art. 10; American Convention on Human Rights, 21 November 1969, 1144 UNTS 123, art. 13.

${ }_{18}^{18}$ UN, Human Rights Committee, Communication No. 633/1995, CCPR/C/65/D/633/ 1995, 5 May 1999, paras. 13.3-14.

219 For the narrow interpretation, see ECtHR, Open Door and Dublin Well Woman v. Ireland, Judgment of 29 October 1992, Application No. 14234/88, 14235/88, para. 55. See also ECtHR, Leander v. Sweden, Judgment of 26 March 1987, Application No. 9248/ 81, para. 74; ECtHR, Gaskin v. United Kingdom, Judgment of 7 July 1989, Application No. 10454/83, paras. 51-52. European Commission of Human Rights, X. v. Federa Republic of Germany, Decision of 3 October 1979, Application No. 8383/78, 228-229; European Commission of Human Rights, X. v. United Kingdom, Decision of 14 December 1979, Application No. 8575/79, 203. 
Today that reading is being abandoned in favour of a new and broader construction of the provisions, endorsing a positive human right to basically access all State-held information. It is in this sense that the multi-stakeholder Atlanta Declaration and Plan for Action for the Advancement of the Right of Access to Information states as its 'key principle' that ' $[\mathrm{a}] \mathrm{ccess}$ to information is a fundamental human right. ${ }^{, 20}$ In Claude Reyes v. Chile, a pioneering judgment of 2006 concerning access to environmental information, the Inter-American Court of Human Rights broadly defined the scope of the right to seek and to receive information under article 13 of the Inter-American Convention on Human Rights as a 'right of all individuals to request access to stateheld information', with the consequence that there is a 'right of the individual to receive such information and the positive obligation of the state to provide it. ${ }^{, 221}$

The European Court on Human Rights has recently scotched its previous narrow reading of article 10 of the ECHR. In 2006 the Court still opined that the right to receive information 'concerne avant tout l'accès à des sources generales d'information et vise essentiellement à interdire à un Etat d'empêcher quelqu'un de recevoir des informations que d'autres aspirent ou peuvent consentir à lui fournir. (...) La Cour observe également qu'il est difficile de déduire de la Convention un droit général d'accès aux donnés et documents de caractère administratif. ${ }^{222}$ In 2009 the ECHR recalled that 'Article 10 does not (...) confer on the individual a right of access' to governmental-held information, and that 'it is difficult to derive from the Convention a general right of access to administrative data and documents.' But then came the obiter dictum: ' $[\mathrm{N}]$ evertheless, the Court has recently advanced towards a broader interpretation of the notion of "freedom to receive information" (...) and thereby towards the recognition of a right of access to

220 'Atlanta Declaration and Plan for Action for the Advancement of the Right of Access to Information', 29 February 2008, available at: www.cartercenter.org, adopted, according to the website by 'over 125 members of the global access to information community from 40 countries, representing governments, civil society orgnizations, interntinity bodies and financial institutions, bodies and financial institutions, donor agencies and foundations, private-sector companies, media outlets and scholars, gathered in Atlanta, Georgia from February 27-29, 2008 , under the auspices of the Carter Center.

221 IACtHR, Case of Claude Reyes et al. v. Chile, Order of 19 September 2006, 2006 Series C No. 151, para. 77

ECtHR, Sdruženi Jihočeské Matky v. Czech Republic, Decision of 10 July 2006, Application No. 19101/03, 9-10. information. ${ }^{223}$ In a recent Grand Chamber judgment, the Court in passing assumed a right 'to receive information in the form of access to the public documents concerned', protected under article $10 \mathrm{ECHR} .{ }^{224}$

Most importantly, the UN Human Rights Commission, in its General Comment on the right to freedom of expression and information, issued in 2011, interpreted article 19(2) International Covenant on Civil and Political Rights (CCPR) as embracing 'a right of access to information held by public bodies.'225 In order to give effect to this right, the Comment further calls upon parties to proactively put in the public domain Government information of public interest. ${ }^{, 26}$ This novel reading is borne out by the wording of article 19(2) CCPR: 'to seek (...) information and ideas of all kinds'.

Legal scholarship has furnished arguments for construing the right to information as a positive right that in principle encompasses a right of access to State-held documents. The purely negative reading of the human right to information is inappropriate to the modern information society. ${ }^{227}$ Normatively speaking, freedom of information should not only be freedom 'from' censorship but a freedom 'to' (in the sense of Isaiah Berlin). ${ }^{228}$ The right to access of public documents should be regarded as a human right because of its 'intrinsic importance' and because it is ancillary to freedom of speech. What is the point of freedom of speech if that speech is badly informed? ${ }^{229}$

Given the important democratic function of citizens' information about government, I submit that a positive but not unlimited right of access to State-held information is adequate in policy terms. It is also fitting under the liberal premise that governmental power is merely a

${ }^{223}$ ECtHR, Társaság a Szabadságjogokért v. Hungary, Judgment of 14 April 2009, Application No. 37374/05, para. 35 (internal references omitted). See also ECtHR, Kenedi v. Hungary, Judgment of 26 May 2009, Application No. 31475/05, paras. $40-43$ on access to documents held by the Ministry of the Interior.

${ }^{224}$ ECtHR, Gillberg v. Sweden, Grand Chamber Judgment of 3 April 2012, Application No. 41723/06, para. 93.

225 UN, Human Rights Committee, General Comment No. 34, CCPR/C/GC/34, 12 September 2011, para. 18. ICCPR, 1966 (n 217), art. 19 had previously been interpreted September 2011, para. 18 . ICCPR, 1966 ( $\mathrm{n} 217$ ), art. 19 had previously been interpreted
by some commentators as providing only access to generally accessible information. See Manfred Nowak, UN Covenant on Civil and Political Rights: CCPR Commmentary (Kehl: Engel, 2nd edn, 2005), art. 19, para. 18.

${ }^{226}$ Ibid., para. 19.

227 Bovens, 'Information Rights' 2002 (n 52); Bröhmer, Transparenz als Verfassungsprinzip 2004 (n 25), 225-229.

${ }^{228}$ Ackerman/Sandoval-Ballesteros, 'Global Explosion' 2006 (n 10), 90.

229 Birkinshaw, Freedom of Information 2010 (n 10), 497-98. 
delegated power; as a US Court of Appeals put it, all information on governmental activity is "information rightfully belonging to the people. ${ }^{, 230}$ If information is public property, government is in principle obliged to share it. As early as 1985 the Inter-American Court of Human Rights had stressed the importance of a free flow of information for liberty and democracy by stating that 'a society that is not well informed is not a society that is truly free. ${ }^{, 231}$ To conclude, the human right to information should be read very broadly and understood as granting access to all State-held information (subject to legitimate restrictions).

There are practical consequences to acknowledging a human right of access to public documents - as opposed to endorsing transparency (only) as an 'objective' (not rights-based) principle of governance. The difference from the law as it stands would be that access to non-public information could not be summarily rejected as falling outside the scope of the human right to information. A positive human right of access to State-held information would not be overly broad because it would not be unlimited. It would still be possible to refuse access on a legal basis in order to protect legitimate overriding objectives as long as the refusal of disclosure is proportionate to those objectives. With a human rights underpinning, the burden of justification in maintaining secrecy shifts to the information-holder. Proportionality - or in ECHR terminology: 'necessity in a democratic society' - would have to be determined by balancing conflicting interests in the concrete case. ${ }^{232}$ Such a human right must also be taken into account when interpreting laws. While a right to information would be neither a necessary nor sufficient condition for bringing about transparency, it could surely reinforce any trend in this direction.

${ }^{230}$ US Court of Appeals, The Detroit Free Press v. Ashcroft, Decision of 26 August 2002, 303 F 3d 681 (6th Cir. 2002), 683.

231 IACtHR, Compulsory Membership in an Association Prescribed by Law for the Practice of Journalism (Arts. 13 and 29 American Convention on Human Rights), Advisory Opinion OC-5/85 of 13 November 1985, 1985 Series A No. 5, para. 70.

${ }^{232}$ Under US constitutional law, government action that curtails the First Amendment right of access to information 'in order to inhibit the disclosure of sensitive information' must be supported by a showing 'that denial is necessitated by a compelling governmental interest, and is narrowly tailored to serve that interest' (US Supreme Court, Globe Newspaper Co., 457 US 606-07 (1982)). Moreover, '[t]he interest is to be articulated along with findings specific enough that a reviewing court can determine whether the closure order was properly entered' (US Supreme Court, Press-Enterprise II, 478 US 10 (1986)). For constitutionally admissible limitations on the right to information under German constitutional law, see BVerfG, 1 BvR 2623/95 of 24 January 2001, on TV reporting in court.

\subsection{Opposable to International Organizations?}

In order to function effectively as a vehicle for global transparency, the human right to information must be opposable to actors other than States. For example, it might be usefully claimed so as to counter World Bank decisions to finance ecologically sensitive developmental projects.

\section{International Human Rights in General}

Such an extension of the obligees of the human right to information would be in line with the overall rationale of human rights. It is the prime function of human rights to protect individuals against public power at whatever level of governance. It is a well-established principle that these rights must be not only theoretical but real and effective. ${ }^{233}$ It is in line with the purpose of human rights that they be opposable not only against State actors but also against inter-State ones such as international organizations, agencies and conferences.

Based upon that teleological consideration, many people demand that international organizations be made addressees of certain international human rights obligations. ${ }^{234}$ Some authors even argue that these duties of international organizations are already part and parcel of international law as it stands. ${ }^{235}$ But there are many open questions, for instance, precisely which organizations are covered, which human rights are thus extended, and which types of obligations (to respect, to protect, or to fulfil) would fall to international organizations.

Is there a doctrinal explanation for the engagement of international organizations in this way? To begin with, the founding documents of

${ }^{233}$ ECtHR, Airey $v$. UK, Judgment of 9 October 1979, Application No. 6289/73, para. 24.

234 From a philosophical perspective, see Cristina Lafont, 'Accountability and Global From a philosophical perspective, see Cristina Lafont, Accountability and Global Global Politics 3 (2010), 193-215.

${ }^{235}$ For the international financial institutions, see Sigrun I. Skogly, The Human Rights Obligations of the World Bank and the International Monetary Fund (London: Cavendish, 2001); Mac Darrow, Between Light and Shadow: The World Bank, the Intents Law (Oxford: Hart, 2003); for the WTO, see Holger Hestermeyer, The WTO and Human Rights: The Case of Patents and Access to Medicine (Oxford University Press, 2007); for the United Nations, see Anne Peters, 'Art. 25', in Bruno Simma et al. (eds.), A Commentary to the Charter of the United Nations (Oxford University Press, 2nd edn, 2012), MN 109-123; and for all international organizations, see Anne Peters, 'The Constitutionalisation of International Organisations', in Neil Walker/Jo Shaw/Stephen Tierney (eds.), Europe's Constitutional Mosaic (Oxford: Hart, 2011), 253-285, 266-269. 
international organizations must be interpreted and applied in conformity with the human rights obligations of their member States. This follows from the principle of interpretation laid down in article 31(3) lit c) of the Vienna Convention on the Law of Treaties (VCLT), which demands that the 'relevant rules of international law applicable in the relations between the parties' must be 'taken into account'. The human rights obligations which all members have incurred are 'relevant' and 'applicable' international rules and must hence be 'taken into account' when interpreting the founding treaties, for example the WTO Agreement or the Statute of the World Bank. Second, any interpretation of those founding documents should complement the basic legal principle that the member States are not allowed to forgo their human rights obligations by transferring competencies to an international organization and that the member States' responsibility continues after any such transfer ('no flight into an international organisation'). ${ }^{236}$ In order to prevent the obnoxious effects of 'up-zoning' public functions to the international level, the member States should retain some residual responsibility. But this does not prevent lacunae if the organizations themselves are not also engaged.

To conclude, the systemic interpretation of the founding documents of international organizations mandates that the organizations take into account the human rights obligations of their member States. This can be understood as a weak type of obligation, comparable to the obligation to protect.

Independent of treaty provisions, international organizations might be fully bound by those human rights which have passed into general international law. ${ }^{237}$ However, although numerous human rights have indeed acquired the status of customary law, it is not clear whether their 'direction' has also changed. The ordinary addressees of obligations flowing from those customary human rights are States. In order to also address the organizations as an obligee or duty-holder, it is not the substance but the structure which would have to evolve so that the relevant obligations were extended to the organizations (besides States). It is doubtful whether such a normative evolution can be

${ }^{236}$ See ECtHR, Matthews v. UK, Judgment of 18 February 1999, Application No. 24833/94, para. 32, with regard to ECHR-member States' 'flight' from obligations under the ECHR.

${ }^{237}$ For the UN, see Iain Cameron, 'The European Convention on Human Rights, Due Process, and the United Nations Security Council Counter-terrorism Sanctions', Report commissioned by the Council of Europe (2006), 21. presumed in the absence of indications to the contrary. ${ }^{238}$ It rather seems that the change of 'direction' would have to be based on a practice and opinio iuris.

\section{The Right to Information}

The 'positive' right to information - the right of access to documents - is effective only when it covers all information which is potentially important for the life of individuals. This includes information concerning the legal position of individuals, policy information, and information that can assist them in bolstering their socio-economic position. ${ }^{239}$ Due to international organizations' relative gain in competencies and power, these types of information are increasingly being held not only by States but also by international organizations. So as not to diminish the value and function of the human right to information, it must be extended to the new information-holders. The Human Rights Committee's General Comment on article 19 CCPR is along these lines. The Comment gives a functional as opposed to a formalist account of the obligees of that right: 'Article 19, paragraph 2 embraces a right of access to information held by public bodies (...) [and] may also include other entities when such entities are carrying out public functions. ${ }^{, 240}$ The Comment also points out that the right of access to information is opposable to 'semi-State entities'. ${ }^{241}$ The soft multi-stakeholder law 'Atlanta Declaration' of 2008 explicitly seeks to bind international organizations to the right to information with a view to furthering transparency: '[t]he right of access to information applies to all intergovernmental organizations, including the United Nations, international financial institutions, regional development banks, and bilateral and multilateral bodies. These public institutions should lead by example and support others' efforts to build a culture of transparency. ${ }^{, 42}$

${ }^{238}$ See in that sense Holger Hestermeyer who argues that the WTO is bound by human rights law because WTO law does not stand in contradiction to that and the WTO has not implicitly contracted out (Hestermeyer, The WTO and Human Rights 2007 (n 235), 99-102. Schermers/Blokker, International Institutional Law 2011 (n 56), 1004-1005 discuss not human rights, but customary norms in general: 'in principle', international organizations are bound by international customary law unless the rule in question is not 'suitable to be applied' to international organizations.

${ }_{239}$ not 'suitable to be applied' to international 'Information Rights' 2002 (n 52).

${ }^{240}$ HRC, General Comment No. 34, 2011 (n 225), para. 18 (emphasis added),

${ }^{241}$ Ibid., paras. 7 and 18.

242 'Atlanta Declaration' 2008 (n 220), principle 3, see also principle 4b). The Atlanta Plan of Action states: '1. Intergovernmental organizations - including the United Nations 


\subsection{Opposable to Business Actors?}

A different question is whether the international human right to information is opposable to multinational corporations. ${ }^{243}$ In my view, the 'Guiding Principles on Business and Human Rights' - as elaborated by the UN special representative of the Secretary-General on the issue of human rights and transnational corporations and other business enterprises - correctly rejects any direct applicability of international human rights to business actors but postulates the business world's moral 'responsibility to respect human rights'. ${ }^{244}$ With a view to our question as to whether transparency is a global standard that is relevant for those actors, the special rapporteur's principles as endorsed by the UN Human Rights Council ${ }^{245}$ and incorporated into the OECD Guidelines for Multinational Enterprises ${ }^{246}$ offer a useful framework: business enterprises have a responsibility to avoid causing an adverse human rights impact through not only their actions but their omissions, too. ${ }^{247}$ Therefore, in the spirit of article 19 CCPR, they must strive to grant the general public reasonable access to information about products and employment conditions. Parallel to this, States have the 'duty to protect' against human rights abuses within their jurisdiction. With regard to the human right of freedom of information, this means that governmental policies, legislation and regulations must strike a balance

and all of its bodies, Council of Europe, Organization of American States, African Union, the Organization for Economic Cooperation and Development and international financial institutes, regional development banks, and trade bodies - and international and domestic non-governmental organizations should give effect to the right of access to information in accordance with the findings and principles enumerated above'. See also de lege ferenda: Stiglitz, 'Democratizing the International Monetary Fund' 2003 (n 123), 111-139, 133: 'TThe IMF, no less than democratic governments, should be subjected to Freedom of Information acts'.

243 Roy Peled, 'Occupy Information: The Case for Freedom of Corporate Information', Hastings Business Law Journal 9 (2013), 261-301.

${ }^{244}$ UN, Human Rights Council, Report of the Special Representative of the SecretaryGeneral on the Issue of Human Rights and Transnational Corporations and Othe Business Enterprises; John Ruggie: Guiding Principles on Business and Human Rights Implementing the United Nations 'Protect, Respect, and Remedy' Framework, A/HRC/ 17/31, 21 March 2011.

245 UN, Human Rights Council, Human Rights and Transnational Corporations and Other Business Enterprises, A/HRC/RES/17/4, 6 July 2011.

${ }^{246}$ OECD, OECD Guidelines for Multinational Enterprises (Paris: OECD, 2011), principle IV.

247 UN, Guiding Principles on Business and Human Rights (New York/Geneva: United Nations, 2011), principle 13 and commentary. between legitimate requests for access and respect for business secrets, and that States must also enforce transparency requirements.

\section{Policy Recommendations}

Because the effects of different transparency measures are still uncertain, policy recommendations can only be quite general.

\subsection{Qualifying Transparency}

De lege ferenda, international law and institutions should be rendered more transparent, i.e. the current trend should be basically continued and reinforced. However, because of the mixed effects of transparency, any move in this direction must be qualified. The question is not so much whether transparency should be created but rather how much and when? Total transparency of international law is neither appropriate nor realistic. Law- and policy-makers should treat transparency as a variable of institutional and legal design. They need to balance the potential negative effects against the positive ones.

Further, a mix of transparent and intransparent elements in institutions, and of transparent and intransparent phases in decision-making and law-making, must be sought. With regard to the World Bank, Philipp Dann speaks of the 'dialectic' of transparency and intransparency as a precondition for the effectiveness of international administration. ${ }^{248}$ So the bottom line is that we need as much transparency as required, but as little as necessary. And how much is that? So far, no clear method has been established to compare and evaluate the costs and benefits of transparency and to allocate the 'right' measure of it. In any case this measure would be sector-specific, for a proper transparency framework must be tailored to specific situations: "[T]here can be no single "how-to" primer on making the best use of what transparency tools can offer for governance. ${ }^{.249}$ A catch-all transparency design is also unwarranted because institutions and the zeitgeist (social expectations and attitudes about what is proper and due) may evolve, and along with them the optimal level of transparency for the international organizations and procedures. David Stasavage gives the EU as an example: ' $[R]$ ather than deciding whether practices such as the club model of multilateral

248 Dann, 'Recht der Weltbank' 2011 (n 91), 320.

249 Florini, 'Conclusions' 2007 (n 77), 337. 
cooperation are optimal in an absolute sense, it may be more accurate to suggest that these secretive forms of international cooperation were desirable at one time, but that they are suboptimal today, in an era where an increasing number of citizens perceive a bias on the part of their representatives. ${ }^{250}$ Finally, transparency mechanisms need to be accompanied by other measures such as participation rights in order not to remain an ersatz policy as discussed above.

\subsection{A Presumption of Transparency}

The need for qualifications of transparency can be translated into a legal presumption. Importantly, a (legal) presumption of transparency should be acknowledged. ${ }^{251}$ The Preamble of the Council of Europe Convention on Access to Official Documents (No. 205) of $2009^{252}$ expresses such a presumption with regard to documents held by States: '[c]onsidering, therefore, that all official documents are in principle public'. Against the background of transparency practices and the assumed opinio iuris, such a presumption arguably already exists as a matter of international law, and not only with regard to States but as regards international organizations. For the sake of legal clarity and certainty, this presumption should also be codified in the constitutions of international organizations or in rules of procedure. ${ }^{253}$

A presumption of transparency means that the non-release of documents and the closure of meetings to the public must be specifically justified on the basis of legal exceptions which have been clearly defined

${ }_{251}^{250}$ Stasavage, 'Open-Door or Closed-Door?' 2004 (n 190), 696.

${ }^{251}$ See Gutmann/Thompson, Democracy and Disagreement 1996 (n 54), 96, explaining the basis 'for a presumption in favor of publicity and the authority of claims of secrecy and other values that could rebut the presumption'; Stiglitz, 'On Liberty' 1999 (n 44), 152. ' $[B]$ ecause of these limitations of legalistic approaches, emphasis must be placed on creating a culture of openness, where the presumption is that the public should know about and participate in all collective decisions'. Buchanan/Keohane, 'Global Governance Institutions' 2006 (n 69), 431: '[T] here should be a very strong but rebuttable presumption of transparency'. Orna Ben-Naftali/Roy Peled, 'How Much Secrecy Does Warfare Need?', chapter 13 in this volume, argue that 'the presumption in favour of secrecy during wartime should be reversed, requiring government officials to shoulder the burden of proof to justify why secrecy is necessary in any particular matter'.

${ }^{252}$ Convention No. 205, 2009 (n 17).

${ }^{253}$ Such as in the 'Note of Interpretation' of the NAFTA Free Trade Commission of 31 July 2001, which makes transparency the 'default norm' in all investor-state complaints brought under NAFTA, chapter 11. See Julie Maupin, 'Transparency in International Investment Law: The Good, the Bad and the Murky', chapter 6 in this volume. and circumscribed prior to the fact. These exceptions can only be granted by stating the reasons for them publicly; the burden of explaining and of proving the need for secrecy is thereby placed on the institution itself - not on those outsiders who request access.

A legal presumption of transparency furthermore generates the obligation to keep the degree of intransparency as low as possible. Institutions must always choose the most transparent alternative to safeguard those objectives that conflict with transparency (protection of deliberations, space constraints, etc.). For example, instead of completely closing a meeting or conference, they must allow a limited number of observers.

With regard to the timing of transparency, a less opaque alternative would be to delay the publication of documents rather than prohibiting publication altogether. But it must be kept in mind that information given ex ante can have a completely different value from the one given only ex post. For example, the publication of deliberations after a treaty text has been adopted by the State representatives is useless with a view to influencing the text itself. Still, any subsequent publication of those deliberations can impact on a parliament's decision to ratify the treaty by better explaining which considerations and factors have in fact led to the text's particular composition.

The presumption of transparency of those holding public power (including international organizations) and the protection of a sphere of privacy and secrecy for citoyen ${ }^{254}$ and bourgeois are two phenomena that do not in fact stand in contradiction to one another but are rather complementary since the non-governmental sphere includes business actors who are not subject to the principle of presumptive transparency. Global transparency remains committed to a principled public-private divide.

\subsection{Meta-transparency}

Intransparency is rendered the more acceptable the more it is embedded in what Thore Neumann and Bruno Simma (chapter 19) have called

${ }^{254}$ For example by protecting the secrecy of political votes. See Hubertus Buchstein, Offentliche und geheime Stimmabgabe: Eine ideengeschichtliche und wahlrechtshistorische Studie (Baden-Baden: Nomos, 2000). 
'meta-transparency'. Meta-transparency or 'second order' transparency ${ }^{255}$ means that the reasons for the intransparency (i.e. whether it is necessary at all) and its substantive and temporal scope must be made transparent. In other words, the questions as to whether, how much and for how long intransparency is warranted (e.g. the need for a closed-door debate, the circumscription of exceptions, possible reform of the policy) must be subject to public debate, ${ }^{256}$ and it is thereby that an 'element of public accountability for the secrecy itself is introduced. ${ }^{257}$

In practice this means that in the administrative sphere the authority's decision to refuse disclosure of a document must (besides striking a fair balance between the conflicting interests) give reasons. ${ }^{258}$ In other words, the (international) bureaucracy's decision to remain intransparent must itself be transparent in order that it be regarded as legitimate. Second, in any dispute settlement, meta-transparency means that even proceedings closed to the general public for security reasons should end at least in a public judgement or award, which is then justified in a transparent fashion. ${ }^{259}$ Third, general rules (e.g. in treaties) which restrict transparency in any issue (for example that of international security) should be transparent in two respects: they should be elaborated in an appropriate combination of closed and public deliberation, and they should be duly published in accessible media. ${ }^{260}$

${ }^{255}$ Gutmann/Thompson, Democracy and Disagreement 1996 (n 54), 105, use the term 'second-order publicity'.

${ }^{256}$ Stiglitz, 'On Liberty' 1999 (n 44), 152

${ }_{257}^{257}$ Gutmann/Thompson, Democracy and Disagreement 1996 (n 54), 104.

${ }^{8}$ In this sense, see EU Transparency Regulation, 2001 (n 61), art. 9(4): ' [A]n institution which decides to refuse access to a sensitive document shall give the reasons for its decision in a manner which does not harm the interests protected in Article 4'.

259 Cf. Council of Europe, Parliamentary Resolution 1551 (2007), 19 April 2007, para. 10.6 .

With regard to domestic laws, the Council of Europe's Parliamentary Assembly stated that 'legislation on official secrecy (...) must be clear and, above all, public'. Council of Europe, Parliamentary Assembly, Fair Trial Issues in Criminal Cases Concerning Espionage or Divulging State Secrets, Resolution 1551, 19 April 2007, para. 10.2. In a parallel fashion, the EU Transparency Regulation imposes procedural obligations on the EU member States for the treatment of sensitive documents, notably the obligation to make public the rules of the institution concerning sensitive documents (EU Transparency Regulation, 2001 (n 61), art. 9(6)). Similarly, the Council of Europe's comparative study of legislation on state secrets in the $\mathrm{CoE}$ member States stressed that any administrative or ministerial decrees giving content to more generally worded statutes must at the very least be publicly accessible' (Council of Europe Rapporteur Christos Pourgourides, CoE Doc. 11031, 25 September 2006, para. 68).
This approach to transparency has consequences for 'deep secrets', whose very existence is hidden from outsiders. ${ }^{261}$ The classic example for keeping a deep secret is the American courts' acceptance of the 'Glomar Response, ${ }^{262}$ which was used by the CIA in a case concerning a sunken Russian submarine. ${ }^{263}$ Here the CIA refused to confirm or deny the existence of any records or documents pertaining to their presumed venture to recover the submarine. In Chapter 6, Julie Maupin gives examples of deep secrets in the international investment-law regime. Meta-transparency means that deep secrets - issues that the public does not realize it does not know - should be avoided. In the end, only metatransparency provides the necessary means for transcending the limits of transparency. ${ }^{264}$

\section{Conclusions}

\subsection{Global Transparency}

This book has sought to analyze the legal status, the functions, potential, legal limits, and legal problems related to transparency in all fields of international law. At the same time, the objective was to place transparency on the agenda of international law research. Due to the complexity of the subject, hardly any ready results can be presented. One thing is clear, however: there is a trend towards more transparency in international governance, as a matter of practice and principle. But only in some areas, this principle has attained the status of hard law. The human right to information is likely to work as a vehicle for increasing transparency, especially if it is understood to be opposable also to international organizations.

Arguably, globalization has rendered more acute the need for transparency at the various levels of governance. There is nothing intrinsic in the international legal system which would prevent an application of

${ }^{261}$ Gutmann/Thompson, Democracy and Disagreement 1996 (n 54), 121. In contrast, a secret is 'shallow' when outsiders know that a piece of information is secret but do no know what the information is. They have at least the opportunity to challenge the keepers of shallow secrets and ultimately decide whether the secret should be kept (ibid.).

262 See Danae J. Aitchison, 'Reining in the Glomar Response', University of California Davis Law Review 27 (1993), 219-254.

263 US Court of Appeals, Military Audit Project v. Casey, Decision of 4 May 1981, 656 F 2 d 724 (DC Cir. 1981), 729-730.

264 See Gutmann/Thompson, Democracy and Disagreement 1996 (n 54), 127, on publicity. 
transparency requirements to that field of law. Within international organizations and courts and tribunals, transparency partly seems to fulfil similar tasks as in the domestic realm, for example as a power shifter, or as a safeguard of judicial independence. But transparency norms can also (for the better or worse) fulfil particular functions peculiar to the international sphere of governance, notably as a kind of ersatz legitimacy. The two phenomena in their combination (national and international transparency) constitute a form of multilevel transparency which is not simply the result of adding national and international transparency but which in itself has a new quality - the quality of global transparency.

The effects of transparency are ambivalent, both 'good' (e.g. by increasing accountability) and 'bad' (e.g. by disturbing diplomatic negotiations). ${ }^{265}$ Law- and policy-makers must therefore balance potential negative effects against expected positive ones and provide for the proper amount of transparency as well as its timely use as adapted to the field of international law, the institutional setting, and the observers at hand. The question is not whether international law should be transparent but to what extent, and what form this should take. Especially with a view to enabling and improving deliberation, public and non-public phases must be mixed, and the design of such deliberation exceptions to general transparency requirements should build on empirical findings on the effects of transparency on the quality of international deliberations. As a general matter, the policy recommendation is that any transparency norm must be qualified, with due exceptions, but starting from a presumption of transparency under which the closure of meetings, the classification of documents, etc. need a specific justification. Also, the exceptions to transparency must be embedded in meta-transparency under which the reasons for intransparency must themselves be made transparent.

\subsection{Towards a 'Public' International Law}

Ultimately the rise of transparency might manifest a paradigm shift, namely international law's shift from a 'private' to a 'public' character. There are two different issues implied in this. The first relates to the fact

${ }^{265}$ As a matter of conceptualization, this ambivalence suggests a need to qualify transparency as an independent principle, and not only as part of a broader principle of global democracy. that traditional international law (being mainly inter-State law) has long been conceived as 'private law writ large'. ${ }^{266}$ Hersch Lauterpacht famously stated that 'formally, international public law belongs to the genus private law'. ${ }^{267}$ The background to this qualification is the traditional distinction between public and private law. But this distinction has been drawn on the basis of different criteria. Public law can be that body of law which is binding on the governing authorities, the law that constitutes and constrains political power (Herrschaft), ${ }^{268}$ or that body of law which seeks to reconcile claims of individual autonomy with the existence of a regime of public authority, ${ }^{269}$ or that body of law intended to serve the general welfare (the common good, the 'public' interest) - as opposed to private law which typically seeks to further private autonomy. 'Public' law can be all of these things - but not always. Despite this epistemic blurriness, despite the historical and geographic contingency of the categories of 'public' and 'private law', ${ }^{270}$ and despite the pitfalls of the domestic analogy, ${ }^{271}$ I submit that the public-law/ private-law distinction also has an analytic and normative value for international law because that distinction reflects the difference between iustitia distributiva (to be realized through distributive policies) and

266 Thomas Holland, Studies in International Law (Oxford: Clarendon Press, 1898), 152. Montesquieu described international law as 'le droit civil de lunivers dans le sens que chaque peuple est un citoyen' (Charles de Secondat Montesqieu, De l'esprit des lois chaque peuple est un citoyen' (Charles de Secondat Montesques De lesprit des lois (Génève: Barrilot \& Fils, 1748), livre vingt-sixième: Des lois dans le rapport qu elles
doivent avoir avec l'ordre des choses sur lesquelles elles statuent; chapitre premier doivent avoir avec de ce livre).

267 Hersch Lauterpacht, Private Law Sources and Analogies in International Law (London: Longmans, Green and $\mathrm{Co}, 1927), 81$.

268 Loughlin, Foundations 2010 (n 26), 1; Dieter Grimm, Das öffentliche Recht vor der Frage nach seiner Identität (Tübingen: Mohr Siebeck, 2012), 72: Public law is described here as the 'Dach aller herrschaftsbezogenen Rechtsmaterien' ('roof of all law related to political authority').

269 Loughlin, Foundations 2010 (n 26), 10-11; Armin von Bogdandy et al. (eds.), The Exercise of Public Authority by International Institutions. Advancing International Exercise of Public Authority by International Institu
Institutional Law (Heidelberg: Springer, 2010), 5.

Institutional Law (Heidelberg: Springer, 2010), 5 .
On the contingency of the public-law/private-law distinction, see the seminal work of On the contingency of the public-law/private-law distinction, see the seminal work of
Martin Bullinger, Offentliches Recht und Privatrecht (Stuttgart: Kohlhammer, 1968). On the reception (or rather re-invention) of the ancient Roman distinction between ius publicum and ius privatum, see Michael Stolleis, 'Öffentliches Recht und Privatrecht im Prozess der Entstehung des modernen Staates', in Wolfgang Hoffmann-Riehm Eberhardt Schmidt-Aßmann (eds.), Offentliches Recht und Privatrecht als wechselseitige Auffangordnung (Baden-Baden: Nomos, 1996), 41-61, 45-51.

${ }^{271}$ It has been claimed that international law is neither public nor private but 'simply "international"' (Alain Pellet, 'Can a State Commit a Crime? Definitely, Yes!', European Journal of International Law 10 (1999), 425-434, 433). 
iustitia compensativa (as realized in the private sphere and through the market). ${ }^{272}$ The emerging transparency norm within international law with its quality as an enabler and to some extent proxy for accountability, participation, and global democracy - is currently strengthening this element of global distributive justice in international law. International law has in that sense been rendered more like 'public' law.

In yet another sense, transparency is both the driver and the manifestation of a paradigm shift to 'public' international law. Transparency seems indispensable to international practices and rules, because the element of transparency supports the qualification of these rules and practices as law in the modern sense. The creation of transparency with regard to those rules is thus apt to fend off resurgent claims that there is no such thing as international law. Lon Fuller has identified various elements as necessary (defining) attributes of law: publicity, nonretroactivity, comprehensibility, no internal contradictions, constancy through time (no frequent changes), and congruence between declared rules and official action. ${ }^{273}$ All of these could also be subsumed under the heading of 'publicness' or for that matter 'transparency'. For Jeremy Waldron, the 'public character of law' lies in 'the fact that law presents itself not just as a set of commands by the powerful and not just as a set of rules recognized among an elite, but as a set of norms made publicly and issued in the name of the public, norms that ordinary people can in some sense appropriate as their own, qua members of the public. ${ }^{274}$ That notion of 'public' has little to do with the public-law/private-law divide, instead referring to all law. 'Public' here connotes a diluted democratic quality: law can be 'public' in that sense even if it has not been created through formally democratic procedures - that is, even if it has not been made 'by' the people but only 'publicly'; when 'ordinary people' can appropriate it and consider it 'as their own' even if they have not voted for it.

Based on this understanding of 'public', Benedict Kingsbury and Megan Donaldson have suggested reconceptualizing international law as an inter-public law which contains basic 'public law' principles that include legality, rationality, proportionality, rule of law and fundamental rights 'as well as (...) an additional quality of "publicness" inherent in

272 See Nils Jansen/Ralf Michaels, 'Private Law and the State', RabelsZ 71 (2007), 345-397, reprinted in Nils Jansen/Ralf Michaels (eds.), Beyond the State: Rethinking Private Law (Tübingen: Mohr Siebeck, 2008), 15-67, 62.

${ }^{273}$ Lon Fuller, The Morality of Law (New Haven: Yale University Press, 1963), 33-41. Jeremy Waldron, 'Can There Be a Democratic Jurisprudence?', Emory Law Journal 58 (2009), 675-712, 684 (emphasis partly added) law'. 275 'Publicness' is 'the claim of law to stand in the name of the whole society and to speak to that whole society. ${ }^{276}$

A pertinent concept - relying on 'publicity' rather than 'transparency' is that of 'public reason' as used in philosophical theories of deliberative democracy. ${ }^{277}$ These theories normally involve a claim about the salutary effects of going public with reasons and arguments. ${ }^{278}$ Their assumption is that having to defend one's policy preferences in public predisposes one towards using public reason. ${ }^{279}$ According to Simone Chambers, public reason involves justification and accountability directed at a public characterized by pluralism. Public reasons (in the plural) are reasons that the public at large could accept. ${ }^{280}$ Publicity (and for that matter, transparency) 'is thought to have a positive effect on deliberation by promoting a democratic mechanism that pushes participants from private to public reason. ${ }^{281}$

Parallel to all this, one strand of political-science and internationalrelations research has undergone a 'deliberative turn'. It claims that arguing - i.e. communicative behaviour on the basis of evolving preferences, in which arguments are given and which seeks to reach a reasoned consensus - is not only an epiphenomenon of power and interest but is constitutive of international relations in its own right. ${ }^{282}$ In this literature, arguing (as just defined) is contrasted with bargaining (understood as communicative behaviour on the basis of fixed preferences in which demands, threats and promises are exchanged). The gist is that arguing can be distinguished from bargaining through its triadic

275 Benedict Kingsbury/Megan Donaldson, 'From Bilateralism to Publicness in International Law', in Ulrich Fastenrath et al. (eds.), From Bilateralism to Community International Law', in Ulrich Fastenrath et al. (eds.), From Bilateralism to Community Interest: Essays in Honour of Judge Bruno Simma (Oxford University Press, 2011), $79-89,80$ and 83 , emphasis added. Inter-public law is not only a series of interactions between states as rational actors but independent of any consensus on a priori principles or morality; ' $[r]$ ather, it is the existence of law that both creates a certain kind of society in its own right, through the practice of seeking law-governed relationships, and allows other communities - or publics - to come into being and assert their interests, by making available certain institutional mechanisms to satisfy public law principles of rationality and rule of law, and by creating rhetorical possibilities for demands that the law respond to the felt needs of a particular public' (ibid., 84).

276 Benedict Kingsbury, 'International Law as Inter-public Law', in Henry S. Richardson/ Benedict Kingsbury, 'International Law as Inter-public Law', in Henry S. Richardson/
Melissa S. Williams (eds.), Nomos XLIX: Moral Universalism and Pluralism (New York Melissa S. Williams (eds.), Nomos XLIX
University Press, 2008), 167-204, 174.

277 University Press, 2008), 167-204, 174.
John Rawls, Political Liberalism (New York: Columbia University Press, 2005), Lecture VI: The Idea of Public Reason, 212-254.

278 Chambers, 'Behind Closed Doors' 2004 (n 135), 390, calls this a 'publicity principle'.

279 Ibid. ${ }^{280}$ Ibid. ${ }^{281}$ Ibid., 392.

${ }^{282}$ Seminally Thomas Risse, 'Let's Argue!', International Organization 54 (2000), 1-39. 
nature. ${ }^{283}$ Arguing involves reference to a mutually accepted external authority so as to validate empirical or normative assertions; and that external authority might be an audience which serves as adjudicator of the better argument; and that audience might be the public observing the negotiations. It is within this paradigm that transparency would appear to be an indispensable element of global governance.

The increasing transparency of international law is in line with the aspirations of these strands of legal, philosophical and IR research. It renders the law-making process more 'public', it makes visible the claim to speak to the entire global society, and it allows natural persons to 'appropriate' it. Transparency is a necessary enabling condition for 'public' discourse on a potential global 'public interest'. ${ }^{284}$ The reason is that in our pluralistic world marked by deep moral disagreement a substantive global public interest can be neither plausibly conceptualized nor identified. We therefore need a legal system which helps in creating and sustaining a 'public sphere' where 'public values' are lived, debated and updated. 285

Ultimately, with the structural change towards presumptive transparency, international law is becoming 'public' law in all those senses mentioned above: a law which constrains political authority, which seeks to reconcile global political authority with individual autonomy, which is in the global public interest ('for' the public), and which is made under scrutiny of the public ('through' the public) even if not fully made 'by' a global public. The new transparency is one of numerous new public-lawlike features emerging in the international legal order and which are contributing to that order's ongoing publification. And this publification is very welcome in that it creates a normativité renforcée of that order.

\subsection{Agenda for Future Research}

While this book attempts to map the terrain of transparency in international law, it has shown that the concept of transparency has many different aspects and functions whose implications for international

${ }^{283}$ Ulbert/Risse, 'Changing the Discourse' 2005 (n 196), 352-353.

${ }^{284}$ On the problem of conceptualizing and identifying a 'global public interest', see Jost Delbrück (ed.), New Trends in International Lawmaking - International 'Legislation' in the Public Interest (Berlin: Duncker \& Humblot, 1997); Simone Peter, Public Interest

285 and Common Good in International Law (Basel: Helbing und Lichtenhahn, 2012). law could only tentatively be explored. The concluding chapter has touched upon a host of conceptual and normative issues that relate to different aspects of transparency but has not drawn (and possibly could not draw) a coherent picture. Further research is warranted both in a conceptual and in an empirical vein.

We have seen that transparency inevitably mirrors its broader political, economic and legal context; but while being shaped by its context, transparency also has the potential to shape it in turn. A key analytical challenge is to identify the conditions under which transparency can indeed unfold any 'transformative potential'. ${ }^{286}$ Empirically, it is not clear whether and under what conditions transparency actually issues in better international law-making, in better application and enforcement of the law, and in generally better outcomes. ${ }^{287} \mathrm{We}$ also need to further investigate under what circumstances public speech (arguing or bargaining) has positive or negative governance effects. ${ }^{288}$ How should closed and open phases of international law-making be combined - and on the basis of which criteria? In order to determine this, a method of comparing and evaluating the costs and benefits of transparency so as to allocate the 'right' modicum of transparency would first have to be developed. However, because of the difficulty, maybe impossibility, of a sensible quantification of the 'costs' and 'benefits' of transparency, such a political-economy approach might not yield useful results.

Further, it is basically an open question as to how effective the existing transparency requirements have been (in terms of compliance and impact). Do they normally realize their objectives, or are they irrelevant or even counterproductive (notably because of evasion)? ${ }^{289}$ It is plausible that the impacts vary across broad issue areas (military, environmental, trade, etc.), and/or between national and international governance. This type of research would face serious challenges because 'natural

${ }^{286}$ Aarti Gupta, 'Transparency as Contested Political Terrain: Who Knows What about the Global GMO Trade and Why Does it Matter?', Global Environmental Politics 10 (2010), Global GMO Trad $48-49$.

${ }^{287}$ For example, Cosette Creamer and Beth Simmons (chapter 10 in this volume) found no evidence of a positive correlation between the mere existence of transparency in the realm of human rights (indicated by the existence of a national human rights institution) and an improvement in human rights.

${ }_{288}$ Building on the research mentioned in nn 195-199.

289 For example, the entry into force of the American 'Government in the Sunshine' Act ' seems to have rest that decision-makers have met informally in private instead (Johnson, 'Open Meeting
and Closed Minds' 2004 (n 201), $25 \mathrm{fn} .47$ ). 
experiment'-type situations are difficult to find. Moreover, large-scale studies cannot take political, social and institutional nuances into account. Therefore, quantitative studies would need to be complemented by qualitative accounts by diplomat officials of international organizations and NGO representatives. The real impact of transparency norms might ultimately not be identifiable because of venueshifting. Researchers could first look at empirical work done on domestic institutions to identify methodologies fit for transposition to international level-research. To be welcomed here are creative proposals regarding institutions which decide and monitor transparency obligations, and settle disputes over disclosure. These would also have to examine how well the novel adjudicative mechanisms established to deal with access to information claims against international organizations function in practice. Finally, legal research might investigate how the domestic freedom of information laws are being used to access information about positions taken by governments in international organizations, or in proceedings before international courts and tribunals. $^{290}$

Engaged legal scholars should be aware of possible political implications and uses of the object of their study. Engaged scholarship must admit that transparency of governance is only a necessary and not sufficient condition for bringing about participation, accountability and possibly democracy in the global sphere. As Ann Florini has pointed out, 'transparency by itself will accomplish nothing at all., ${ }^{291}$ It would be naïve to assume that information, once set free, will generate an informed and engaged public that will hold officials accountable. ${ }^{292}$ Information must not only be made available, but be taken up and interpreted and used for political reaction. All this requires not only capacities (ranging from sufficient literacy to technical knowledge) but also a willingness on the side of the recipients of information, as well as the means to overcome obstacles such as countervailing economic interests. There is no automatic progress from global transparency to protodemocratic forms of self-determination of a global citizenry. Therefore,

${ }^{290}$ This is an idea by Megan Donaldson.

${ }^{291}$ Florini, Coming Democracy 2003 (n 121), 38. See also Hale, 'Transparency, Accountability and Global Governance' 2008 (n 8), 74-76 on the 'transparancy-arency, cycle'.

${ }^{292}$ Mark Fenster, 'The Opacity of Transparency', Iowa Law Review 91 (2006) 885-949, 915 . and because of the costs associated with generating more transparency, the idea should not be oversold - it is no 'magic bullet'. ${ }^{293}$ Where, when, and how a transparency principle, possibly as a legal norm, can and should come to bear in international law and global governance deserves further research.

${ }^{293}$ Lord, Global Transparency 2006 (n 76), 125. 